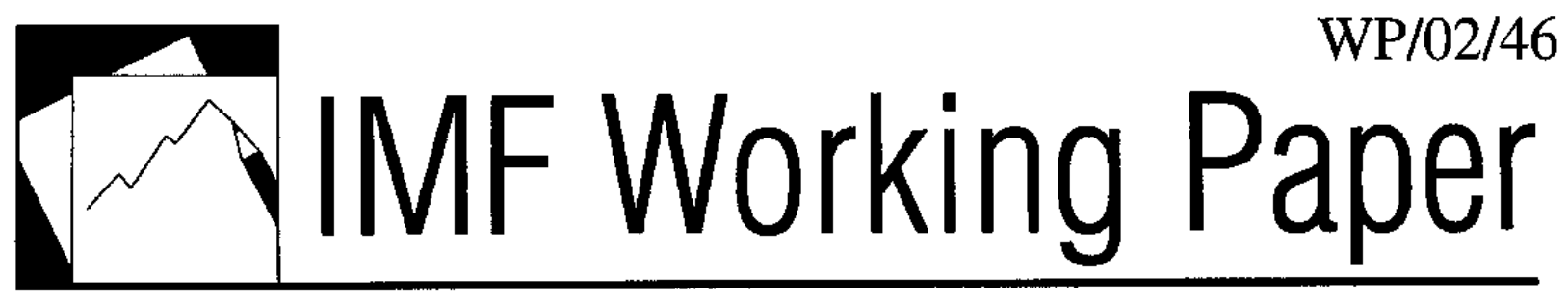

\title{
Regulatory and Supervisory Independence and Financial Stability
}

Marc Quintyn and Michael W. Taylor 


\title{
IMF Working Paper
}

Monetary and Exchange Affairs

\section{Regulatory and Supervisory Independence and Financial Stability}

\author{
Prepared by Marc Quintyn and Michael W. Taylor ${ }^{1}$ \\ Authorized for distribution by David S. Hoelscher
}

March 2002

\begin{abstract}
The views expressed in this Working Paper are those of the author(s) and do not necessarily represent those of the IMF or IMF policy. Working Papers describe research in progress by the author(s) and are published to elicit comments and to further debate.
\end{abstract}

Despite its importance, the issue of financial sector regulatory and supervisory independence (RSI) has received only marginal attention in literature and practice. However, experience has demonstrated that improper supervisory arrangements have contributed significantly to the deepening of several recent systemic banking crises. In this paper we argue that RSI is important for financial stability for the same reasons that central bank independence is important for monetary stability. The paper lays out four key dimensions of RSI-regulatory, supervisory, institutional and budgetary - and discusses ways to achieve them. We also discuss institutional arrangements needed to make independence work in practice. The key issue in this respect is that agency independence and accountability need to go hand in hand. The paper discusses a number of accountability arrangements.

JEL Classification Numbers: G18; G28; K23; L50

Keywords: Financial Regulation, Banking Supervision, Regulatory Agencies, Agency Independence, Central Bank Independence

Author's E-Mail Address: mquintyn@imf.org; mtaylor@imf.org

\footnotetext{
${ }^{1}$ We would like to thank our IMF colleagues Peter Hayward, Dong He, David S. Hoelscher, Yuri Kawakami, Inwon Song, and participants at an IMF seminar, as well as Professor Charles Goodhart (Bank of England), Rudi Bonte and Fernand Naert (Belgian Commission for Finance) for their valuable comments and suggestions. We would also like to thank Silvia Ramirez for her skillful research assistance in compiling the appendix, and Natalie Baumer, Funke Fasalojo, Monica Snyder, and Sandra Solares for editorial and secretarial support. The usual disclaimer applies.
} 


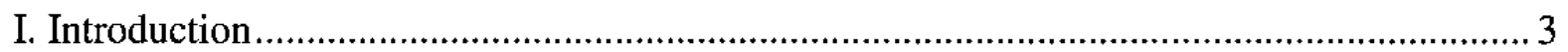

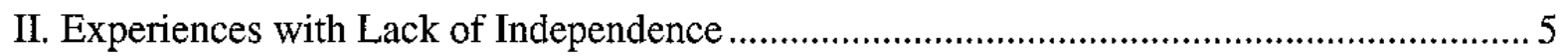

III. The Case for Agency Independence ...................................................................... 7

A. The Case of Financial Regulation and Supervision ........................................ 8

B. The Case for Agency Independence ............................................................. 8

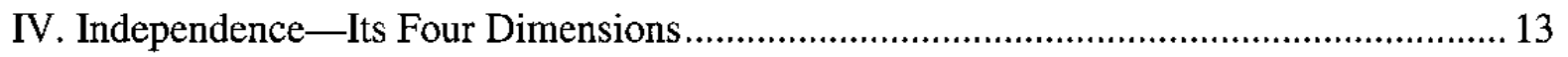

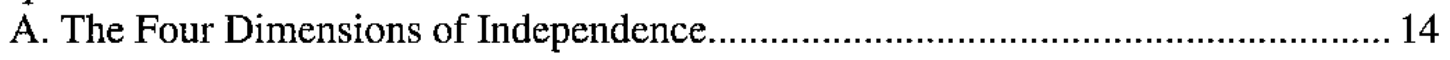

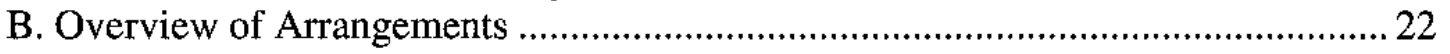

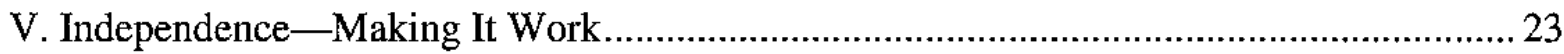

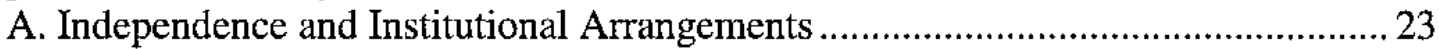

B. Independence and Political Checks and Balances............................................. 27

C. Political Control, Governance, and Accountability......................................... 29

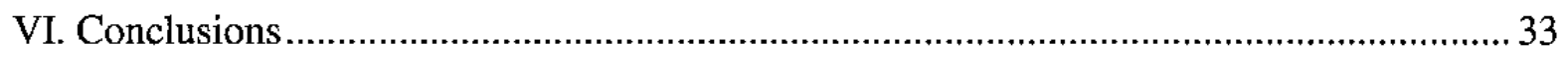

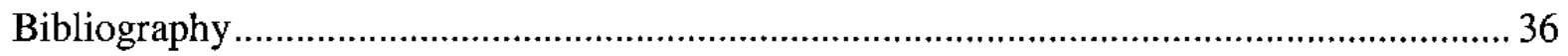

Boxes

1. The Case for CBI: Overview of the Arguments...................................................... 12

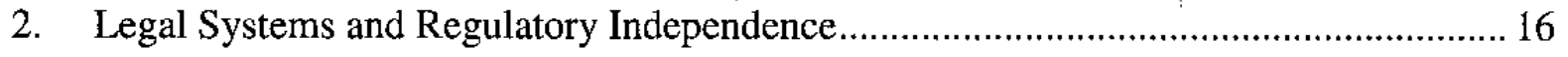

Appendix I. Overview of Features of Autonomy of Banking

Supervisors in Selected Countries........................................................................ 41 


\section{INTRODUCTION}

This paper argues that bank regulators and supervisors need a substantial degree of independence--both from the government and the industry-in order to fulfill their mandate and contribute to the achievement and preservation of financial (sector) stability. It also contends that regulatory and supervisory independence (RSI) complements central bank independence (CBI) to achieve or preserve the twin goals of monetary and financial stability. At the same time, given the crucial role of banking supervision, the paper argues that proper channels of accountability need to be established as the countervailing power to agency independence.

Although an increasing number of papers are being written about regulatory and supervisory issues, RSI has not been discussed in a systematic way. A survey of the existing literature indicates that scholars either make only a passing mention of it, or take its desirability for granted without much further analysis. ${ }^{2}$ The reasons why regulatory independence might be desirable and the conditions under which it can be achieved have not hitherto received a thorough examination. This paper aims to remedy this deficiency.

Two factors have served to give the need for RSI greater prominence in recent years. First, in almost all of the systemic financial sector crises of the 1990s, the lack of independence of supervisory authorities from political influence has been cited as one of the contributing factors to the deepening of the crisis. ${ }^{3}$ Weak and ineffective regulations-often because politicians block the adoption of stronger regulations - weak and dispersed supervision, and political interference in the supervisory process leading to regulatory forbearance have been mentioned as major factors contributing to the weakening of the banks in the run-up to the crisis, postponing recognition of the severity of the crisis, and delaying first official and subsequently effective intervention.

A second factor to have highlighted the importance of RSI is the discussion on the most appropriate regulatory and supervisory structure, including the organizational structure of banking supervision within or outside the central bank. The growing tendency to move to unified (or integrated) financial sector supervision often involves removing the banking supervision function from the central bank, where it had previously enjoyed a relatively high degree of independence derived from the central bank's independence with respect to its monetary policy functions. On the one hand, there is a concern that removing banking supervision from the central bank will create a less independent function than previously

${ }^{2}$ The Basel Core Principles on Effective Banking Supervision have certainly drawn attention to the topic. Core Principle 1 explicitly requires that the bank regulatory agency possess "operational independence and adequate resources."

${ }^{3}$ See for instance De Krivoy (2000) on the Venezuelan crisis of the mid-1990s and Lindgren and others (1999) on the East Asian crisis of 1997-98. 
existed, also because discussions about unification have revealed greatly varying levels of independence among regulatory agencies, leading to a debate about the appropriate degree of independence for the new, unified agency. ${ }^{4}$ On the other hand, the creation of a supervisory superpower raises fears about too great a degree of power for this institution-in particular if the institution becomes part of the central bank-thereby reopening the unsettled debate about well-established accountability.

The case for RSI will be made by drawing on analogies with two areas where the case for independence has been already well established. The first is the regulation of public utilities and other economic sectors where sector-specific oversight is required because of externalities. A vast literature is now available arguing that regulatory independence accompanied by solid accountability in general leads to more effective regulation and more competitive, healthier and better structured sectors than when regulation and supervision is left to the line ministries without clear mandates for consumer welfare. However, financial sector regulation and supervision differs in key respects from the regulation and supervision of other economic sectors because of the public good function associated with financial stability. Hence, the second analogy is CBI, for which the arguments are now well established. Specifically, the paper argues that the independence of regulatory agencies matters from the point of view of financial sector stability for many of the same reasons that the independence of central banks matters for monetary stability and that independence of both agencies will reinforce each other in achieving the overall goal of financial stability. ${ }^{5}$

To make the concept of RSI operational, the paper sets out four dimensions of independence-institutional, regulatory, supervisory, and financial. We discuss the importance of each of these dimensions and suggest ways to achieve them. Because of the key role of the supervisory function, it will receive more attention than it typically receives in the literature on agency independence. ${ }^{6}$

Arrangements for agency independence are by themselves not sufficient for effective regulation and supervision. Institutional arrangements matter, the prevailing political culture

\footnotetext{
${ }^{4}$ It is self-evident that the arguments in favor of independence apply to all subsectors of finance.

${ }^{5}$ A similar point is made by Lastra (1996) p.151.

${ }^{6}$ The literature on agency independence often only refers to "regulators" either because the regulatory function is the dominant function, or in their dual function of regulator and supervisor. With respect to the financial sector it is important to keep in mind the distinction between both functions. As Quinn (1998) argued, both jobs might be performed by one and the same person, but they perform different tasks-respectively rule-setting and ruleimplementation and enforcing - with different implications from the point of view of the topic of this paper, as will be emphasized. The reader should bear in mind that when this paper uses the word "regulators," it is only for the sake of conciseness.
} 
matters, and, most of all, proper accountability measures are fundamental to make independence work. The paper reviews first the arguments in favor of and against housing the supervisory function in the central bank, as well as the arguments used in the recent tendency to integrate sector supervisory functions. It is recognized that RSI could benefit from the independence of the central bank, as well as from the fact that several central banks have received regulatory powers in their charters. On the other hand, conflict of interest and the danger of reputational damage are arguments against having supervision in the central bank.

Subsequently, the need for checks and balances in the government system to make independence work is emphasized. The fewer checks and balances there are, the easier and less costly it is for the authorities to override or undermine agency independence. Given that a vast number of countries do not have well-established systems of political checks and balances, it is argued that other strategies are needed to convince governments of the importance of not meddling with the financial sector, in the name of economic growth and development. Assessments of the Basel Core Principles for Effective Supervision could be instrumental in this regard, but interference in the supervisory work is harder to bring to a halt.

Finally, the paper stresses that the key to effective regulation and supervision implies setting up proper accountability arrangements for the independent agency. Unbalanced independence may open the door to industry capture or self-interest; the creation of new institutional rigidities; over-regulation, which may lead to additional costs for the industry; a slowdown in structural adjustment in the sector; and lack of communication with other layers of government. Rather than regarding independence and accountability as being on a continuum, involving trade-offs between the two objectives, the paper argues that it is possible to structure institutional arrangements in such a way that these objectives can be seen as complementary. We provide a set of criteria to ensure good regulatory governance.

The paper is structured as follows. Section II sets the stage by providing a few obvious examples where the degree of independence appears to have been inadequate. Section III reviews the case for agency independence and financial sector RSI. Section IV presents four dimensions of independence in the typical case of financial sector regulation and supervision. It also provides an overview of selected country arrangements in terms of the dimensions of RSI. Section V discusses arrangements to make independence work: institutional arrangements, the need for checks and balances in the political system, and the issue of political control, governance, and accountability. The chapter formulates a number of suggestions to establish accountability. The main conclusions are presented in Section VI. The appendix presents an overview of independence and accountability arrangements in selected countries.

\section{EXPERIENCES WITH LACK OF INDEPENDENCE}

The case for RSI can be supported by the actual experience of a number of countries where inadequate arrangements to ensure the independence of the regulatory agencies have 
contributed to the emergence of financial instability. ${ }^{7}$ Protection of weak regulations by politicians and forbearance as a result of political pressures (preventing the regulators from taking action against institutions that they were aware needed to be intervened) are the two most common types of undermining the integrity of the supervisory function. This section reviews a few cases.

Korea prior to the 1997 crisis provides one example of the effects that a lack of independence can have on banking supervision. Commercial banks were under the direct authority of the monetary board (the governing body of the Bank of Korea) and the Office of Banking Supervision. Specialized banks and nonbank financial institutions were under the direct authority of the ministry of finance and economy. The ministry's supervision of the nonbanks was generally recognized as being weak and, moreover, created conditions for regulatory arbitrage and excessive risk-taking, especially among commercial banks' trust businesses and merchant banks, which was a contributing factor to the 1997 crisis. $^{8}$ In addition, the supervisors had the authority to waive requirements, which led to widespread forbearance and which made enforcement nontransparent. (Lindgren and others, 1999). In the wake of the crisis, in recognition of the weaknesses of supervision, Korea has reformed it supervisory system to provide it with more autonomy and to eliminate the regulatory and supervisory gaps.

In Japan, the lack of independence of the financial supervision function within the ministry of finance is also widely believed to have contributed to the emergence of financial sector weaknesses (Hartcher, 1998). Although there was probably little direct political pressure on the ministry of finance to exercise forbearance, the system lacked transparency and was known for widespread implicit government guarantees of banking sector liabilities. Following a decline in the ministry's reputation as a supervisor in the late $1990 \mathrm{~s}$, the Japanese government

${ }^{7}$ The case for RSI can certainly also be supported by cases were proper arrangements prevented problems from developing. However, given the confidential nature of the supervisory function, it is easier to provide examples of inadequate arrangements that led to banking problems, than to provide examples of cases where adequate arrangements forestalled problems, and many such cases certainly exist. Or, as Goodhart (1998) noted, "Supervisory failures have to become public, but supervisory successes in averting crises have to remain secret, at least for a time." (p. 54).

${ }^{8}$ In general, in the East-Asian crisis (1997-98), there were very strong indications that political interference in the regulatory and supervisory process postponed recognition of the severity of the crisis and, therefore, delayed action and deepened the crises. In some cases, supervisors were aware of the severity of problems in some financial institutions or subsectors, but political pressure inhibited them from tackling these problems. Similarly, practices of forbearance and lifeboat schemes to extend the life of problem banks inspired by political motives in earlier periods raised expectations that such behavior would continue, leading to moral hazard and inaction on the part of the supervisors (Lindgren and others, 1999). 
decided to create a new Financial Supervisory Agency, which would oversee banking, insurance, and the securities markets and would be more independent and transparent than the ministry of finance had been. The Japanese Financial Services Agency (FSA) is responsible to the prime minister's office rather than to the ministry of finance, an arrangement that was the result of the authorities' desire to remove the potential conflicts of interest inherent in the ministry's role as both the regulator and the promoter of the financial services sector (Hartcher, 1998). However, to the extent that the intention was to create a more transparent and decisive agency, the results to date have been disappointing. Perhaps one factor contributing to these problems may have been a lack of attention to the external conditions required for effective agency independence (see Section IV. B. below). ${ }^{9}$

Political interference in financial sector supervision is perhaps at its most pronounced in decisions to intervene a bank or to provide it with government funds for recapitalization. In Indonesia during the Habibie presidency, the Financial Sector Action Committee (FSAC), comprising a number of ministers of economics and chaired by the coordinating minister, made a number of intrusive interventions into the activities of the Indonesian Bank Restructuring Agency (IBRA). For example, FSAC intervened to reject shareholder settlements that had been negotiated by IBRA management and to demand that the bank recapitalization scheme favor the indigenous business community over banks that were "Chinese" (Enoch and others, 2001).

These political interventions served to undermine the credibility of the bank restructuring effort, and particularly the requirement of uniformity of treatment. Just like day-to-day supervision, the credibility of bank restructuring is significantly enhanced if it is under the direction of an agency with a strong and independent board.

In her account of the Venezuelan banking crisis of 1994, Ruth De Krivoy lists ineffective regulation, weak and dispersed supervision, and political interference as major factors contributing to the weakening of the banks in the run-up to the crisis. ${ }^{10}$ Among the wealth of lessons that she draws from this deep crisis, she strongly argues that lawmakers should "make bank supervisors strong and independent, and give them enough political support to allow them to perform their duties" (De Krivoy, 2000, p. 207).

\section{The CASE For Agency IndePENDENCE}

This section briefly reviews the need for financial sector regulation and supervision and builds the case the RSI. We thereby draw on analogies with agency independence in other sectors as well as CBI.

\footnotetext{
${ }^{9}$ Part of the confusion arises from the existence of a minister for financial services whose position is not recognized in the legislation, but who steers the agency and acts between the agency and the prime minister.
}

${ }^{10}$ See De Krivoy (2000). 


\section{A. The Case of Financial Regulation and Supervision}

A government needs to secure a credible commitment to regulation, pursuing only the tasks that are necessary to correct unambiguous instances where the private sector, left to itself, produces market failures or suboptimal results compared to a situation with public regulation. The three main reasons for regulation are (a) to avoid the danger of monopolistic exploitation; (b) to promote systemic stability (the externalities argument); and (c) to provide protection for smaller, less informed clients (the information deficiencies argument) (Goodhart, and others, 1998, p. 4). Cases (b) and (c) certainly apply to the financial system and, as such, justify government regulation of the sector.

However, compared to other sectors where regulation is justified on the basis of the above criteria (utilities, communications, and other sectors producing externalities), the financial system (and in particular the banking system) performs a special function in the economy that justifies a more elaborate system of regulation and supervision. This special-and indeed unique - function is that the sector plays a key role in the achievement of financial stability, which is now generally considered a public good. ${ }^{11}$

Achieving the goal of financial stability not only justifies more public regulation but also a more prominent role for supervision than in any other sector, where supervision typically remains at a more superficial level and is mainly compliance-driven. Banking supervision takes the form of off-site analysis, extensive on-site inspections, and several additional types of monitoring and/or intervention when financial institutions enter the "trouble zone." The banking supervision function may even include "court-type" powers to resolve troubled institutions, whereby very fundamental issues, like the taking away of ownership rights, need to be dealt with. The implications of the key role of supervision will be analyzed in subsequent chapters.

\section{B. The Case for Agency Independence}

\section{General considerations}

Once the need for public regulation has been established, the focus moves to the most effective institutional arrangement to organize and enforce regulation and supervision. Over time, various arrangements have been tried to achieve this goal, but theory and practice are converging on the view that independent regulatory agencies offer the most adequate solution to the need for good regulatory governance.

\footnotetext{
"1 See, among others, Crockett (1997), White (1996), and Goodhart (1998). The latter disaggregates this special role of banks into several areas (a) their pivotal position in the financial system, especially in clearing and payments systems; (b) the potential systemic dangers stemming from bank runs; (c) the nature of bank contracts; and (d) adverse selection and moral hazard associated with the lender-of-last-resort role and other safety net arrangements that apply to banks. Each of these aspects are building blocks of financial stability.
} 
Delegation by the legislature of the authority to regulate has been common practice for several decades. The main motive for delegation is the amount of work involved in regulating and supervising specific social and economic activities and sectors, in combination with the growing complexity of such work. Such delegation can take two forms. The first approach, delegation to a government agency, a specific minister, a local authority, or another official body, has been common practice in most countries for many decades.

The second type, delegating regulatory powers to independent agencies-as opposed to government agencies - is of a more recent origin and not (yet) as widespread and accepted. ${ }^{12}$ In addition to the advantages associated with the first type of delegation, independent regulatory agencies theoretically offer the advantage of potentially shielding market interventions from political interference and improving transparency, stability, and expertise of the regulatory and supervisory process, particularly when responses are needed for complex situations.

Agency independence has two dimensions--independence from political interference and freedom from "regulatory capture." Agencies that suffer from regulatory capture identify industry interests (or even the interests of individual firms within it) with public interest. The fear of industry capture was popularized by Stigler's (1971) seminal article that stimulated the principal-agent debate. He demonstrated that bureaucracies respond to the wishes of the bestorganized interest groups rather than to political directives or to the public interest. This fear of capture by interest groups has been heightened in the case of independent regulators because, by definition, political control is weaker, and therefore the risk for capture by other groups greater. Just like political pressure, industry capture can indeed play a role in undermining the effectiveness of regulation. ${ }^{13}$ Rules may be formulated with a view to minimizing industry costs, rather than striking an appropriate balance between costs and benefits. Rules may also be applied inconsistently, with individual firms winning case-by-case exemptions from regulatory requirements.

On the other hand, the need for political independence has created a long-standing fear-also part of the principal-agent discussion-that independent agencies would be outside political control, not be politically accountable, pursue their own agendas that may go against the agenda of the political majority in democratic regimes, or-see above-be captured by

\footnotetext{
${ }^{12}$ Independent regulatory agencies have existed in the United States since the 1890 s (the first one was the Interstate Commerce Commission, which became the model for other similar bodies, including the Securities and Exchange Commission), even though their actual degree of independence has varied over time, in line with political moods. In other OECD countries, such bodies have been established in more recent years, fueled by such factors as privatization of formerly publicly-owned utilities, reform in Europe inspired by the Single Market, WTO agreements, and by policy advice from IFIs.

${ }^{13}$ Political oversight has indeed often been justified on the grounds that regulatory capture needs to be contained.
} 
private interests. ${ }^{14}$ Some authors have branded independent regulators as the "fourth branch of government", implying that they were outside the control of the traditional three branches that, through checks and balances, keep mature democratic systems in equilibrium. These justified fears point to the need for proper accountability mechanisms to balance the advantages of agency independence, as will be discussed in Section V.

Achieving both types of independence, political and industrial, is essential. However, the element of political independence draws special attention from the point of view of financial stability, given the vested interests that many national governments still have in banking and, therefore, in bank regulation and supervision. There is a long and diverse track record of evidence of political interference leading to a weakening of regulatory and supervisory arrangements. In the specific case of financial institutions, industry capture could in some cases be a disguised form of political capture if bank owners are politically connected.

Regulatory reform of utility sectors and other economic sectors that are deemed to produce externalities, has been the worldwide focus in recent decades. A growing body of empirical evidence provides support for the view that independent regulators in these sectors have lent more efficiency and effectiveness to the regulatory process and led to smoother and more efficient operations of the markets. The Organization for Economic Cooperation and Development's (OECD) work in this area has been quite instrumental. Independent regulatory agencies are increasingly seen as a necessary component of modern regulatory governance, and as such, represent a sound improvement when compared to regulatory functions embedded in government ministries without clear mandates or objectives (OECD, 2000). Jacobs (1999) points at the growing evidence that the market impact of market opening in the telecom and public utility sectors has been the greatest where independent regulators have been most prevalent. Also, in a study on the history of regulatory agencies in the United States, Wood and Waterman (1991) conclude, "... the agencies most responsive to executive influence, gauged by the magnitude and duration of change, were those situated in the executive departments... On the other hand, the agencies with the most stable output were the independent regulatory commissions" (p. 823).

\section{Central bank independence and RSI}

The growing recognition that financial and monetary stability are two sides of the same coin when it comes to macroeconomic stability, invites to arguing for RSI along the same lines as for CBI. Moreover, monetary and financial stability interact very closely. Thus, it can be argued that (a) bank regulatory and supervisory independence is for financial stability what central bank independence is for monetary stability; and (b) that independence of the two agencies in charge of monetary and financial stability would have a mutually reinforcing

\footnotetext{
${ }^{14}$ Kane's work (Kane 1990) on the savings and loans crisis (S\&L) in the United States for instance, shows that supervisors were swayed by self-interest to behave in ways that do not maximize social welfare.
} 
effect. ${ }^{15}$ The unique position of financial sector regulators and supervisors and the central bank with respect to the public good function of financial stability distinguishes these two agencies from other regulatory agencies in that their function is broader than that of other sector-specific regulators.

Two analogies between the case for CBI and RSI are worth exploring. First, if the authorities wish to ensure the safety and soundness of the financial system they need to establish a credible and stable set of regulations, which include rule-based exit policies for weak or insolvent financial institutions. Short-term political objectives do not always coincide with this need for a clear and stable set of rules and regulations. Politicians can notoriously be influenced by short-term factors-ranging from the latest newspaper headlines to a large donation from a wealthy supporter, or pressure from mighty economic sectors. For these reasons they may be tempted to interfere with the regulatory (and supervisory) process to achieve an outcome that fits in with their immediate goals. But interference has its costs, especially the loss of consistency in regulatory decision-making and the creation of moral hazard. If the regulatory function is not perceived to be stable and credible, and the rules by which the sector is regulated are subject to political pressures, potential investors may defer investment decisions and the development of financial markets and institutions will be hampered by a regulatory system unable to demonstrate the necessary degree of independence from political interference. Similarly, if supervisory intervention is perceived to be ad hoc, or biased, the agency loses its credibility.

The second analogy is directly related to the time inconsistency literature (Box 1). Bank liquidations are typically politically unpopular since they can result in genuine hardship for depositors and other creditors, many of who will also be voters. Vote-maximizing politicians with shorter time horizons than supervisors may be concerned about the short-term costs of bank closure, whether fiscal, in terms of lost votes, or in terms of lost campaign contributions and will be sensitive to demands of these groups, particularly if they are politically wellorganized. Politicians may be tempted, as a result, to put pressure on supervisors to organize a bailout, exercise forbearance or grant dispensations from regulatory requirements to avoid short-term costs. But short-term forbearance may be the cause of higher longer-term resolution costs (Macey and Miller, 1997). Another way of looking at the issue is that, because of the intertemporal nature of financial contracts, the implications for the government budget of delayed resolution of problems banks are not obvious to the politicians. Hence the need for qualified, well-informed and independent supervisors.

\footnotetext{
${ }^{15}$ Increasingly, central banks are taking an active interest in financial stability from a macro stability point of view (several central banks, including The Bank of England, the National Bank of Hungary and the Riksbank of Sweden have started publishing financial sector stability reports), and these efforts are complemented by the supervisors who take an interest from the micro stability point of view. See Brealey and others, 2001 for an overview.
} 
Accordingly, politicians face the same incentives in relation to failing banks as they do in relation to the goal of price stability. This would imply that any preannounced rule-based policy for financial sector resolution set out by a government department would not be believed by rational agents, who include bank owners and managers. The latter may be tempted to undertake high-risk activities in the belief that the authorities' reaction function in practice will differ from the preannounced rules. Hence the need for an agency with a substantial degree of autonomy.

\section{Box 1. The Case for CBI: Overview of the Arguments 1/}

The modern case for $\mathrm{CBI}$ relies on the inflationary bias that otherwise would be present in monetary policy. It attributes the inflationary bias either to the dynamic inconsistency of monetary policy over time or to the revenue motive of the inflation tax. The latter occurs when the fiscal authority weighs the social cost of inflation inappropriately.

The dynamic inconsistency of monetary policy is a special case of the time inconsistency literature (Kydland and Prescott, 1977). Time inconsistency emphasizes the need for a credible and binding precommitment to a particular mandate that prevents violations ex post. According to the theory of central bank independence, politicians seek to maximize their own welfare, especially short-term electoral gain, rather than the public good. It also assumes that voters feel the immediate benefits of government attempts to stimulate the economy, but they do not experience the inflationary consequences for up to 2 years later (i.e., after an election has been held). These factors suggest that politicians have a strong incentive to prefer economic expansion. Given that politicians face such an incentive structure, rational agents will disbelieve the authorities' commitment to price stability and behave in ways that prevent the authorities from achieving their original goals. Central bank independence is one wayalthough not the only way-of formulating a credible and binding commitment to price stability. One way of achieving credible commitment, as Rogoff (1985) argues, is to place monetary policy in the hands of a person or institution who weighs inflation deviations more heavily than in the social welfare function-the "conservative central banker."

1/ For a review of the literature on CBI, see e.g., Eijffinger and de Haan (1996); Gros and Thygesen (1992); Alesina and Summers (1993); Cukierman, Webb, and Neyapti (1992).

An important objection to this analogy is the argument that the incentives faced by regulators differ from those faced by conservative central bankers. This is, in essence, the critique of regulatory forbearance developed by Kane (1990). In this account, regulatory forbearance arises from the self-interested actions of regulators rather than those of politicians; the incentive structure faced by regulators encourages them to "sweep problems under the carpet" at least until the regulator has left office. While Kane's analysis is important in drawing attention to the need to consider regulators' incentive structures, remuneration arrangements, and accountability measures, many would argue that his analysis takes an unduly cynical view 
of the motivation of most regulators whose observed behavior does not correspond to that predicted by this model. Moreover, to the extent that Kane has built his model on the observed behavior of regulators during one particular episode - the S\&L problem in the United States alternative analyses of the same episode place greater emphasis on political interference than on the self-interested behavior of regulators in triggering the crisis. More generally, politicallyinduced forbearance is more likely to occur than regulator-induced forbearance.

There is one important difference between RSI and CBI - and by extension, between RSI and the general debate about agency independence. As Lastra and Wood (1999) note, RSI would give supervisors to some extent "the coercive power of the state against private citizens" when they are involved in revoking bank licenses. This is a power that has no equivalent in the powers given to independent central banks. Far-reaching though granting of these powers is, this should not be used as an argument against granting independence. On the contrary, as argued in later sections of this paper, the implications of granting such powers should be fully accepted, namely by recognizing (a) the need for well-established accountability arrangements to prevent abuse from this power; and (b) the need for high-qualified and well-paid supervisors of high integrity.

\section{INDEPENDENCE-ITS FOUR DIMENSIONS}

With RSI, as with CBI, it is useful to distinguish at the outset between goal independence and instrument independence (Fischer, 1995). This distinction enables us to separate the overall objective which the regulatory agency is required to achieve, and which is established in the law creating the agency, from the actual formulation and implementation of supervisory and regulatory policies ("instrument independence") that can be safely left to the judgment of specialist officials. Hence, politicians have a proper role to play in setting and defining regulatory and supervisory goals, but regulators need to have the autonomy to determine how they should achieve them-and also be accountable in the event that they fail to achieve them.

To make the notion of instrument independence operational, we identify four different dimensions or building blocks that together define independence-regulatory, supervisory, institutional and budgetary independence. The regulatory and supervisory dimensions form the core, while institutional and budgetary independence are essential to support the execution of the core functions. Regulatory and supervisory independence can hardly be achieved without solid arrangements underpinning institutional and budgetary independence. They provide the operational independence that underpins instrument independence. Disaggregating the monolithic concept of independence also allows one to some extent to consider different 
combinations that offer a satisfactory degree of independence in a given constitutional, political, and institutional framework and to tailor the accountability arrangements accordingly. ${ }^{16}$

\section{A. The Four Dimensions of Independence}

\section{Regulatory independence}

Regulatory independence refers to the ability of the agency to have an appropriate degree of autonomy in setting (technical) rules and regulations for the sectors under its supervision, within the confines of the law. In addition to the main arguments that justify regulatory independence in general - fast action when needed, stability, and expert input in the process-two sector-specific arguments should be emphasized.

The first one concerns the imperatives posed by internationalization. Given the importance, complexity, and growing internationalization of the financial sector, regulators need to be in position to adapt prudential rules and regulations quickly and flexibly to international best practices, in response to changing trends, conditions, and dangers in the international marketplace. ${ }^{17}$ The second one is an ownership argument. It can be expected that supervisors will identify themselves better with the task of rule-implementation and enforcing, if they have been closely involved in the rule-setting process as well.

Regulatory agencies that need to go through an often lengthy and slow political process to adjust technical rules and regulations face at least two dangers. First, precious time might be lost (typically up to 1 year and sometimes 2 years) before new rules or regulations are adopted in the political process. Second, involvement of the political process may bear the risk that rules and regulations, which are technical in nature and which are based on international best practices and standards become contaminated with political considerations, depending on the strength of checks and balances in the system.

An often-cited danger of regulatory independence is that the over-zealous regulators over-regulate the market and do not take into account the cost of regulation of the sector. In an extreme case the high cost of regulation may deter foreign investors and put the country at a disadvantage. While this is a real danger, it is not unique to independent regulators. Governments can also over regulate sectors. The other disadvantage is regulatory capture by the industry. Proper transparency in the rule-making process, combined with mechanisms for consultation with all parties involved, is a method to reduce the dangers of these disadvantages.

${ }^{16}$ However, as will become clear from the discussion in this chapter, the margin for manoeuvre for weighing the four dimensions is limited if it is the authorities' goal to commit to effective independence.

${ }^{17}$ Calomiris and Litan (2000, p. 290) strongly emphasize the need for supervisors and regulators to respond quickly to changing international conditions and trends, thereby implicitly arguing for a proper degree of autonomy. See also Hayward (2002) for similar arguments. 
To focus the discussion on the degree of regulatory autonomy that is desirable, it is useful to divide financial sector regulations into three main categories: economic regulations, encompassing controls over pricing, profits, entry, and exit; ${ }^{18}$ prudential regulations, involving controls over the type of products or production process chosen by the supervised firms; and finally, information regulations, governing the information that needs to be provided to the public at large and to the supervisors.

Depending on a country's legal traditions and culture, these three types of regulations can, at one extreme, be dealt with in detail in the law on financial institutions and/or the law governing the operations of the supervisory agency. At the other extreme, these laws only brush a broad framework and rules and regulations are needed to complement them (Box 2).

Typically, the economic and information regulations are not subject to too many adaptations over time and could, therefore, be left to the lawmakers, following a consultation process with the supervisors.

However, the story regarding prudential regulations is different. Prudential regulations cover general rules on the stability of the business and its activities (legally required minimum amount of capital, and fit and proper requirements for senior management), as well as specific rules that follow from the special nature of financial intermediation (risk-based capital ratios, limits on off-balance sheet activities, definition of limits on exposure to a single borrower, limits on connected lending, foreign exposure limits, loan classification rules, and loan provisioning rules). These are the fundamental rules upon which the supervisory process rests and which have a large impact on the soundness of the banking system. From the point of view of regulatory independence, a high degree in autonomy in setting prudential regulations is a key requirement to ensure that the sector complies with international best standards and practices.

Although the principle of regulatory autonomy seems widely accepted, it is nevertheless not generally applied and experience shows that this type of rule setting has in several countries been prone to political interference, with severe consequences in terms of financial instability. ${ }^{19}$ The appendix indicates that there are, on the one hand, several regulatory agencies that have full autonomy in this area while, on the other hand, there are also a host of agencies that have no regulatory powers at all. The appendix also contains country examples where the delineation of legal responsibilities between supervisors and the government is very vague.

${ }^{18}$ Entry and exit policies and their supervision is discussed in the section on supervisory independence, because the issues are predominantly related to the implementation of the policies.

${ }^{19}$ For example, in some countries the authorities have lowered loan classification standards and provisioning rules for loans to economic sectors that face temporary or structural problems in order to facilitate lending to these sectors. Exposure rules to large borrowers are often relaxed to allow specific industries or companies to survive. 


\section{Box 2. Legal Systems and Regulatory Independence}

While regulatory independence is a key element among the four dimensions of independence, it is also the one that in some countries faces the most hurdles to implement because it touches upon fundamental issues embedded in the constitution and often rooted in century-long legal traditions.

Broadly two different systems can be identified within which, in practice, wide differences exist in terms of legal tradition.

On the one hand, in some countries, based on constitutional practice, primary legislation and secondary legislation are so detailed that little room is left for rules and regulations. The laws, in particular the secondary legislation, cover all the details. In other traditions, primary and secondary legislation is kept general in nature, leaving ample room for regulatory initiatives at the technical level and at the level of implementation.

Under the first system, the room for regulatory independence by agencies is highly limited. At best agencies are allowed to issue (nonbinding) guidelines or clarifications. As a rule agencies are consulted on new laws, amendments or revisions. A major drawback of this legal tradition is that amendments and revisions often take long because of the political process. In a fast changing environment like banking and finance, this can be harmful.

Under the second system, regulatory independence is greater because the agency can fine-tune technical regulations in a fast way and, therefore, stay in tune with essential market developments.

This paper argues that broad powers to issues rules and regulations should be given to regulatory agencies for the reasons explained in the text. To circumvent the obstacles posed under the first system, some countries have granted their central banks status of a special agency in the constitution, so that it can issue regulations on the matters that fall under the bank's purview. A similar approach could be taken for regulatory agencies that are not located in the central bank.

Irrespective of the country's legal traditions, legal arrangements should be made to give supervisors large discretion to set and change them flexibly within the broad confines of the country's constitution and the banking law. For those countries where legal traditions and practices do not allow independent agencies to have regulatory powers, consideration should be given to whether exceptions can be granted based on the importance of the financial sector regulatory and supervisory function, as has been done in some countries with respect to the central bank. 20

${ }^{20}$ Sometimes independent central banks have been granted binding regulatory powers over their specific sector. 


\section{Supervisory independence}

The supervisory function with respect to the financial sector is much more developed and crucial than in most other sectors of the economy because of the public good aspect of financial intermediation. On-site inspections and off-site monitoring, sanctioning, and enforcement of the sanctions-including revoking licenses-are the supervisors' main tools to ensure the stability of the system. Safeguarding the integrity of the supervisory function is, therefore, a key element in ensuring the soundness of the financial system.

Following Lastra (1996), we divide the supervisory function into four areas: licensing, supervision sensu stricto, sanctioning and crisis management. We first deal with supervision in the strict sense as well as aspects of sanctioning. Licensing and revoking licenses (the ultimate sanction) are the topic of the subsequent paragraphs. Crisis management is beyond the topic of this paper because it involves other government agencies and a specific approach. ${ }^{21}$

While supervisory independence is so crucial for financial sector stability, it is even more difficult to establish and guarantee than the other dimensions of independence. To preserve its effectiveness, the supervisory function is typically highly invisible. But exactly this invisibility makes it vulnerable to interference, both from politicians and the supervised. Political interference (and interference from the industry itself) can take many forms and can indeed be very subtle, making it difficult to safeguard (shelter) the supervisors from any form of interference. $^{22}$

Government interference, very often under the form of granting forbearance--letting institutions continue to breach regulations unpunished, not enforcing sanctions-takes place in many countries. In isolated cases, it may lead to the prolongation of the life of insolvent institutions (and, therefore, lead to unfair competition and higher costs for the taxpayer at a later stage), whereas in other cases it may threaten the stability of the sector and lead to systemic problems.

At least four ways should be explored to increase or safeguard the integrity of the supervisory function, including the sanctioning:

- Bank supervisors (supervisors in general) should enjoy legal protection when executing their job. In many countries, supervisors can be sued personally for their actions. The absence of proper legal protection works in many instances paralyzing.

\footnotetext{
${ }^{21}$ On this topic, see Lindgren and others. (1999).

${ }^{22}$ Assessment of compliance with the Basel Core Principles for Effective Banking Supervision often encounters this problem as well. While it is relatively easy to assess compliance with those principles that cover regulations, it is much more difficult for the assessor to assess compliance with those principles covering the supervisory practice.
} 
Supervisors are afraid of imposing sanctions or enforcing them, for fear of being sued by the supervised institution. In cases of banking crises, when quick and drastic measures are needed (such as bank closures), the entire process can stall, and the crisis spread further, if the supervisors lack the legal protection to take such measures. This issue was explicitly mentioned in the case of the Philippines. Proper legal protection of supervisors should be established in the banking law and be transparent. ${ }^{23}$

- The introduction of a rules-based system of sanctions and interventions would remove the scope for discretion in individual cases. A rules-based system has the advantage of being more transparent and also of being amenable to judicial review than the exercise of discretion; it thus reduces the scope for decisions to be influenced by factors other than an objective assessment of the technical merits of the case. An example of a rules-based approach is the use of prompt corrective actions in the regulatory framework (PCAs) ${ }^{24}$ PCAs were introduced in the United States following the S\&L crisis (1991) and are now being introduced or considered in several other countries. While in the United States PCAs were primarily designed to insulate the regulatory process from self-interested actions by the regulators themselves, ${ }^{25}$ the existence of such objective parameters in the law may protect supervisors who work in good faith in several countries where political intervention is part of the culture, or where state-owned banks play a dominant role in the financial system. Admittedly, there is a trade-off between the drawbacks of taking away some of the supervisors' discretion and the gains in terms of protection and independence.

- Appropriate salary levels for the supervisors and clear career streams can also help to ensure supervisory independence. In many (mainly developing) countries salary levels of supervisors are low. This has two effects. First it opens the way to bribery. Second, it makes it impossible for the agency to attract the best supervisors-or to keep them once they are in the agency. So the quality of the supervisory function suffers and less qualified staff are most likely more open to influencing by outsiders than high quality staff.

- The banking law should at the same time be very specific about, and limit, the layers of decisions as well as the process of, and time allowed for, appeals by institutions that have been sanctioned by supervisors. Banking laws in several countries allow excessive appeals to the court system. Such possibility has several disadvantages. First it allows institutions to prolong their existence under unsound conditions that may affect the

${ }^{23}$ See Delston (1999) for an overview of country practices as well as recommendations as to how to include proper stipulations in the law.

${ }^{24}$ See also Goodhart and others (1998, p.54-55) for similar arguments.

${ }^{25}$ See, among others, Vives (2000a) and Boot and Thakor (1993). 
health of the entire system; second, it undermines the integrity of the supervisory function and the reputation of the supervisor by allowing nonexperts to intervene in the process; third, it distracts the attention of the supervisor from other issues because of the possibility of getting mired in months or years of controversy; and fourth, the risk of industry (or political) capture becomes higher if financial institutions can intimidate the regulator/supervisor through the court or political system. The agency may become more willing to soften regulations or interventions to avoid similar controversies in the future. Reasonable systems for appeal should be provided for, but they should be such that they do not affect the integrity of the supervisory function or damage the interest of the depositors. To avoid undue interference of nonexpert courts, specialist tribunal could be established, as has been done is some countries.

The process of licensing institutions and withdrawing licenses should ideally be left to the supervisory agency, Because supervisors are in charge of supervising the institutions during their lifetime, they should also have the final word as to who can enter the system and who should exit from the system and how, and thus how to shape the sector (in terms of size and numbers). Practice varies greatly among countries (Appendix). Indeed, "Licensing is the key first step in the supervisory process" (Lastra, 1996). A typical situation that may lead to problems is one where the government (ministry of finance or council of ministers) has the final say over the licensing of individual banks, with supervisors ending up in a situation with too many banks-and, even worse, too many small and unsound banks-- to supervise with too small a staff.

The same degree of autonomy should apply when it comes to exit procedures, based on the same argument that supervisors are in the best position to decide on the viability of individual banks. But there is another argument: the supervisors' power is much more persuasive if they can threaten to remove the license. If that power is in the hands of another government agency or the minister himself, the threat can be empty. ${ }^{26}$ However, both processes-granting and revoking licenses--should be highly transparent.

The case of mergers (and by extension acquiring significant stakes) needs special attention because mergers in general are part of the responsibility of the national competition authority (if there is one) and sometimes the central bank also plays a part in the decision. ${ }^{27}$ The

\footnotetext{
${ }^{26}$ We thank Peter Hayward for bringing this critical point to our attention. However, Boot and Thakor (1993) argue that based on the bad experience during the S\&L crisis (the Kane criticism), supervision and intervention should be separated into two institutions. In our view, the arguments put forward in this paper are stronger than the Kane criticism, which needs to be put in perspective. Therefore, the case for separation of those two activities seems weaker than the case for keeping them together under the umbrella of one supervisory agency.

${ }^{27}$ Merger control responsibility in the financial sector varies from country to country. In several European countries, like the United Kingdom, Switzerland, the Scandinavian countries, and France, responsibility for approval is shared between the competition authority and the
} 
optimal division of labor in the case of merger approval should involve the supervisory agency because of its expert knowledge of the financial sector, and the competition authority, both on equal footing with each other. Such an arrangement would be consistent with the independence of the supervisory agency.

\section{Institutional independence}

Institutional independence refers to the status of the agency as an institution separate from the executive and legislative branches of government. An agency that forms part of the executive branch, such as the ministry of finance, typically lacks independence. For an agency that needs to respond quickly to changing markets - dictated by both domestic and international changes in the environment-it is crucial to possess a high degree of institutional independence. The following are three critical elements of institutional independence:

- The terms of appointment and-even more critically-dismissal of its senior personnel. Independence is best served if there are clear rules on hiring and firing, which should depend on regulators' competence and probity, not on the decisions they reach. Under such rules regulators would enjoy security of tenure, enabling them to speak and take action without fear of dismissal by the government of the day. Ideally two government bodies--that is, government and parliament-should be involved in the appointments process.

- The agency's governance structure. Multi-member commissions help ensure consistency and continuity of decision-making over time and are less likely to be influenced by the views of any one individual. However, it is crucial that these commissions be composed of experts (for instance a retired banker, or finance professor, but not representatives from specific ministries).

- The openness and transparency of decision making. Inevitably many decisions involve commercially sensitive material that would be difficult to disclose. But the presumption should be in favor of openness in the decision-making process, making it possible for both the public and the industry to scrutinize regulatory decisions minimizing the risk of political interference. As discussed later in this section, one arrangement to achieve a high degree of institutional independence is for the supervisory agency to be part of the central bank and to benefit from the latter's autonomy and prestige.

supervisory authority. In practice, the central bank or the supervisory agency carries a lot of weight in the decision (Vives, 2000b). In Italy, the central bank approves bank mergers and the competition authority has only a consultative role. In the United States, bank mergers must receive approval of the regulator (Federal Reserve, FDIC, or OCC-depending on the case) but the Department of Justice can (and actually does) challenge mergers that threaten to reduce competition substantially. 


\section{Budgetary independence}

Budgetary independence refers to the role of the executive/legislature in the determination of the size of the agency's budget and its use, including staffing of the agency and salary levels. Supervisors who can independently decide over the sources, size and use of their budget in function of their mission are better equipped to withstand political interference (pressure through the budget), to respond more quickly to newly emerging needs in the area of supervision and to ensure that through attractive salaries competent staff is hired. The other side of the coin is that independence from the government may lead to dependence on the industry that could open the door for industry capture.

Supervisory agencies that are funded through a ministry that exercises oversight of their operations, or directly from the budget, may be open to political interference of different sorts. Their budget can simply be too small to attract highly qualified supervisors and pay marketrelated salaries; or their budget might be cut at times of fiscal austerity - and those times often coincide with mounting problems in the banking system, needing greater supervisory attention. Funding through the government can also be (ab)used by the latter to organize other types of interference in the supervisory process. Cases can be imagined where the government threatens to withhold funding (or squeeze it) if the supervisors are deemed to be too strict on politically linked financial institutions. If, for whatever reason, there is a consensus that funding needs to come from the government budget, the supervisory budget should be proposed and justified by the agency, based on objective criteria related to developments in the markets.

Alternatively, several supervisory agencies are funded through the beneficiaries of regulation (the customers of financial services), which in practice means via a levy on the regulated industry, or a combination of such levies and government funds. Fee-based financing has several advantages such as avoidance of political interference, and more freedom for the agency to set its budget in line with its (objective) needs. But unless the levy is properly structured it may produce a sense of budgetary dependence on the industry that could undermine the agency's autonomy in other ways. To avoid industry capture and ensure that the fees are reasonable, in some countries, their level is determined jointly by the supervisory agency and the government. Other accountability measures can be envisaged to ensure that the independent supervisor does not abuse its rights.

One of the downsides of fee-based funding of the supervisory agency is the conflict that may arise when, in times of economic downturn or financial crisis, more intense supervision and monitoring requires more resources from the industry, which in those times may face problems raising these resources (because of lower profits or because the size of the sector is shrinking). In the worst case, such a situation may force a lay-off of supervisors exactly at times that they are needed the most. Recently, U.S. supervisory authorities have been facing this problem. Allowing the agency to build up reserve funds for these periods seems the best solution.

Supervisory agencies that are part of the central bank structure are, as a rule, either funded as part of the central bank, or from industry-fees. As part of the central bank budget, 
these supervisory agencies enjoy the same financial autonomy as the central bank. In theory this sounds like the ideal solution. However, situations can be envisioned whereby a power struggle within the central bank has a negative impact on the budget and the staffing of the supervisory agency.

\section{B. Overview of Arrangements}

It is worthwhile to digress briefly to form an idea about current arrangements in terms of RSI. The appendix to this paper provides, for a selected number of countries, an overview of key elements of independence and accountability. The countries are grouped based on the location of the supervisory agency (inside central bank, inside ministry of finance, in a separate location, or having hybrid arrangements).

The overriding finding is that the degree of autonomy of banking supervisory agencies is very uneven among countries, even among countries whose financial systems have been developing in parallel (such as the OECD countries). Indeed, regulatory and supervisory agencies come in very different shapes and sizes. Arrangements and areas of authority differ widely, basically indicating that legal and institutional traditions play the largest part in shaping regulatory and supervisory functions in each and every country. Similarities and differences, in particular in regulatory powers run across the four groupings. ${ }^{28}$ The following are some additional observations:

- In a minority of countries, the regulatory and supervisory functions are an integral part of a ministry (usually ministry of finance). By definition, these agencies have no independence from the government.

- Having regulatory independence (the power to issue binding rules and regulations) seems to depend more on legal traditions in the country than on the location of the supervisory agency. In a set of countries, supervisors have the power to issues rules and regulations within the confines of the law on financial institutions, whereas in other countries, supervisors can only issue (nonbinding) guidelines. In other cases, the borderline is unclear.

- A similar observation applies to the right to grant and withdraw licenses, although in this case supervisors located outside the central bank, more often than not, have the sole rights in the licensing and delicensing process. In general, practice ranges from the government or the ministry of finance having sole responsibility, to arrangements where

\footnotetext{
${ }^{28}$ For instance, although transition economies have a recently reformed oversight system, differences in legal traditions (going back to earlier in the twentieth century) dictate differences in legal powers: in Hungary the regulators have no regulatory powers, while in Poland and Czech Republic they do have regulatory powers. Additional overviews of aspects of institutional arrangements can be found in Barth, Caprio, and Levine (2001) and Healey (2001).
} 
a consultation process prevails, to countries where the supervisors have total independence. Typically, governments want to reserve for themselves more rights in the exit process than in the entrance one.

- Budgetary independence is guaranteed more when supervisors are housed in the central bank, although there is less information on the allocation process of funds within the central bank. Many supervisory agencies are funded through fees from the industry. Sometimes these fees go directly to the agency, in other cases they go (partially or totally) to the agency either through the central bank budget or the government budget. Finally, in a number of cases, supervisory agencies are funded directly from the government budget, which in principle leaves them without much autonomy in budgeting, staffing, and salary policies.

- Accountability differs widely, both in arrangements and strength. In several cases the laws are not very specific. For separate agencies, practices vary in terms of appointment procedures, but more often than not it is clear to whom the president of the agency is accountable. When supervision is housed in the central bank, most often the president of the latter bears ultimate responsibility, but it is not always clear to whom, and to what extent, the head of supervision can be held accountable.

- Finally, recently reformed supervisory authorities (following mergers of sectoral supervisory agencies) have a higher degree of independence than their predecessors, with the FSA in Japan being the exception.

\section{INDEPENDENCE-MAKING IT WORK}

The previous chapter discussed the vital ingredients for RSI. However, granting independence is a necessary but not sufficient condition for its effectiveness. This chapter analyzes arrangements and conditions needed to ensure that independence actually works. We first discuss the impact of institutional arrangements on RSI. Subsequently we lay out requirements in the broader political framework. Last but not least, this chapter discusses the need for proper agency accountability as a necessary complement for agency independence, an area that deserves more attention than it has received thus far.

\section{A. Independence and Institutional Arrangements}

It could be argued that perhaps the simplest way to secure an appropriate degree of independence for financial services regulation is for the function to be located in the central bank. Given that CBI in the past two decades has increasingly found recognition, one could argue that supervisors could "piggyback" and enjoy (or build up) the same degree of autonomy and prestige. The case for combining banking supervision with the monetary policy function has 
been extensively examined. ${ }^{29}$ The following paragraphs briefly review the arguments from the RSI point of view.

The chief argument for combining both functions is that banks are the instruments through which monetary policy is transmitted to the wider economy and therefore the central bank should be concerned with their soundness as a precondition for an effective monetary policy. In addition, since the central bank also acts as a lender of last resort it should have access to information about the financial condition of the institutions that might potentially apply to it for emergency liquidity assistance. The more recently advanced argument that central banks are concerned with macrostability and supervisors with microstability of the sector, points out that both functions are two sides of the same coin, justifying close cooperation and coordination. ${ }^{30}$

There are also a number of powerful arguments in favor of a separation of both functions, stemming from the potential for conflict of interest in a multi-objective institution. A central bank might be tempted to operate a lax monetary policy if it is concerned about the financial health of banks it is also responsible for supervising. By keeping monetary conditions loose, the central bank may avoid the failure of banks for which it might be blamed, but at the expense of higher inflation in the longer run.

Conflict of interest and reputational damage are closely linked. The failure of individual banks can attract blame to the bank supervisors and thus undermine the credibility of the central bank if it is also the bank supervisor. Thus, it is argued, it is better for the central bank's relationship with routine banking supervision to be at a relatively arms-length distance to avoid such reputational contagion. The argument in favor of an arms-length relationship also holds from the supervisors' point of view. Their reputation can be damaged if central bank actions tend to prolong the life of an institution when supervisors have come to the conclusion that it needs to be liquidated. More generally, Wilson (1989) argues that successful organizations tend to have a clear and singular mandate. Supervisors may perform better in a single-objective institution because chances are smaller that their reputation and, therefore, their career paths are damaged by conflicting actions by other officials of the central bank (Vives, 2000a).

Whether issues like conflict of interest or reputational damage might arise or not, would largely depend on the specific institutional settings. For instance (a) supervisors could be subject to oversight by a central bank board composed of outsiders, appointed by the government or specific ministries, whose presence could alter the supervisory decision-making

\footnotetext{
${ }^{29}$ An overview of the arguments are provided in Goodhart and Schoenmaker (1998). A recent publication (Hawkesby, 2001) sheds some additional light on the discussion, adding cost-benefit elements and country-specific factors.

${ }^{30}$ However, it should be remembered that cooperation and coordination can also be achieved when both functions are housed in separate agencies.
} 
process; or (b) the overseeing board-through its composition-could be biased toward monetary policy considerations and, therefore, overrule or change supervisory decisions. The outcomes of the decision-making process would also depend on who bears the final responsibility over supervisory actions--the governor of the central bank or the head of the supervisory department. What these examples demonstrate is that it should not be taken for granted that supervisors located in the (independent) central bank de facto enjoy the same degree of autonomy as the central bank.

The arguments for separation and combination of functions are thus finely balanced, but two considerations would appear to tip the weight of argument in favor of combining both functions in transition and developing economies. These central banks often have very strong guarantees of independence from political pressure, in some cases being established as independent entities under the respective constitutions. In many of these countries the governor of the central bank enjoys a high degree of security of tenure, with the central bank, itself, having its own dedicated funding sources. Moreover often the central bank has-as an exception from the legal tradition-been given the power to issue regulations in specified areas.

A subsidiary reason for combining both functions in transition and developing economies is that the central bank is usually better placed to attract and retain staff with the right level of skills and expertise than are other government agencies, owing to its relative budgetary autonomy and prestige. This means that central banks are often much better placed to develop the human resources necessary for high quality regulation than are government departments (or newly established agencies). This is the model that most transition countries have adopted with a few exceptions.

However, as a nonbank financial sector begins to emerge in these economies, these markets and institutions must be adequately supervised. Moreover, the trend towards the formation of large financial groups not only makes the need to supervise them acute, but also creates the need to coordinate supervision of the respective sectors and brings the issues of appropriate autonomy arrangements to the forefront.

If banking supervision is located in the central bank, both for the reasons usually cited and to provide a stronger guarantee of regulatory independence, then one option might be for the central bank to assume these other regulatory functions as well. The benefits of this approach are that it ensures that these regulatory functions will also be performed with the same independence as banking supervision and that regulatory capacity building will be facilitated by the central bank's prestige and access to human resources. Combining all financial regulation within the central bank would permit significant scale economies to be realized by using its information technology, data collection, and human resource functions. 
However, relatively few countries in the world have adopted this approach, ${ }^{31}$ perhaps reflecting a number of serious drawbacks about this type of regulatory structure. ${ }^{32}$ In the first place, it involves the central bank taking on responsibility for a wide range of financial activities about which its staff can be expected to have no special expertise. Second, the extension of the central bank's regulatory responsibilities to nonbank financial institutions may appear to be an implicit extension of its guarantee of financial assistance beyond banks. Third, and most importantly, granting the central bank such extensive regulatory responsibilities may result in it being perceived as excessively powerful. Such a powerful central bank raises issues of accountability, at times that there is still a lot of discussion about the contents of accountability in general.

A possible alternative to centralizing all regulatory and supervisory functions in the central bank would be to create an integrated financial regulatory authority, as a separate regulatory agency responsible for banking, securities, and insurance regulation. In terms of RSI, the issue is mainly to ensure that the highest level of independence be achieved. Very often sectoral regulators and supervisors have highly different levels of independence stemming from historical backgrounds and it will be the task of the authorities to ensure that, instead of the lowest common denominator, the highest level of independence can be established. ${ }^{33}$

In sum, whatever the preferred option is, if supervision is housed in the central bank, the latter's independence arrangements should not be taken for granted to argue that RSI is also ensured. Proper arrangements have to be put in place to guarantee that (a) operational autonomy underpins the work of the supervisory agency; (b) the central bank has regulatory autonomy as defined above; and (c) the integrity of the supervisory function is guaranteed.

${ }^{31}$ The main examples are Singapore and the Netherlands Antilles. See Courtis (2001).

${ }^{32}$ For a more extensive discussion of advantages and drawbacks, see Abrams and Taylor (2000), Goodhart (2000), and Taylor and Fleming (1999).

${ }^{33}$ The institutional arrangements underpinning regulatory agencies indeed vary greatly from country to country and across types of agencies (banking, securities, insurance, and pension funds). In countries with a well-rooted financial system (mainly OECD countries), typically bank supervisors and regulators have a higher degree of independence from the political authorities than agencies supervising other sectors. For instance, traditionally, insurance supervisors were established as a department within a ministry (finance or economy) and their supervisory functions were limited. The growing importance of the insurance sector as a part of large financial conglomerates is changing this situation, leading to "emancipation" of insurance regulators and supervisors. Supervision and regulation of the securities sector varies widely across countries, from government departments to independent agencies, to self-regulatory organizations, an arrangement unique for the sector. 


\section{B. Independence and Political Checks and Balances}

Establishing or preserving the integrity of the regulatory and supervisory function depends to a large extent also on the prevailing (political) culture. In a number of western countries independence is greatly buttressed by the transparency of political processes, the presence of numerous checks and balances in the political system, the role of the media, and the absence of a close government-business nexus. However, in many other economies-transition and others - these elements of the environment in which regulatory agencies operate are either lacking or still in the course of being developed, and hence even greater attention must be given to the institutional arrangements to ensure independence.

The discussion starts again from analogies with recent reviews of the effectiveness of independent central banks. ${ }^{34}$ These reviews have come to the view that arrangements that grant independence to the central bank, even if accompanied by solid accountability arrangements, do not always yield the expected results in terms of policy effectiveness. These authors conclude that the broader political institutional conditions under which the politicians commit to an independent central bank are a key factor for the actual degree of independence.

Granting independence to a central bank is shown to be only credible in legislative systems with at least two heterogeneous decision-making bodies (Moser 1999). In a system with extensive checks and balances, once independence has been granted to an agency, it cannot be removed by a simple majority rule. So, in a legislative system with at least two veto players with different preferences, the costs of withdrawing the independence (or interfering in the policymaking process) are great, and higher than in a system with few (or no) checks and balances. Therefore, supplying agency independence becomes more credible and independence leads to more effective (monetary) policy making in systems with political checks and balances. Previous literature on central bank independence - and on regulatory independence in generallargely neglected the existence of such costs, or considered them exogenous.

Keefer and Stasavage (2001) provide empirical evidence that an independent central bank is most effective (in terms of reducing inflation) in the presence of political checks and balances, and that political interference with the central bank is more present when there are few checks and balances. They conclude that prestige alone-however important-is insufficient to guarantee independence. Political institutions are crucial to the sustainability and effectiveness of decision making by independent agencies.

The parallel with financial regulatory agencies is straightforward. Although no empirical evidence is as yet available on the relationship between political checks and balances and the effectiveness of regulatory independence, Keefer (1999) offers an interesting overview of the

${ }^{34}$ See for instance Franzese (1999), Moser (1999), and Keefer and Stasavage (2001). 
linkages based on intuitive reasoning. ${ }^{35}$ The presence of checks and balances in the system seems, on balance, to have a positive effect on the effectiveness of the independent agencyprovided proper accountability mechanisms are in place. For instance, the presence of checks and balances tends to better insulate the supervisors in their function and it may drive up the incentives to have good and more prudent regulations. The fewer checks and balances there are, the more incentives there are for the government to override, at no cost, supervisory actions (or pre-empt them) in the case of a troubled bank, and keep that bank open. Government-induced forbearance is likely to be a more common phenomenon in a political system with few(er) checks and balances. Similarly, relaxing key prudential rules, for instance to favor specific economic sectors, are less costly when checks and balances are underdeveloped.

In a crisis environment, a system with multiple checks and balances has, by definition, no unrepresented groups onto which the costs of a financial crisis can be off-loaded. Therefore checks and balances are perceived to exert more pressure to correct weak regulations and to avoid a crisis at an early stage through supervisory intervention. However, to the extent that intra-government negotiations may slow down the initial response to a beginning crisis, they may have a negative impact (i.e., cost increasing) as they could increase the magnitude of a crisis. On the other hand, because all interest groups are represented, everyone has an advantage in limiting the cost of a crisis, so the positive impact is likely to offset the negative one and make the outcome most likely better than in a system without checks and balances.

While the conclusion of these findings is straightforward-RSI and accountability can only be effective in a conducive political culture - the policy implications are less clear. It takes time for such a political culture to take root. ${ }^{36}$ Given this political reality, the message for countries with political systems that lack checks and balances is that the commitment to RSI should be based on the view that adherence to best international standards and practices is becoming a necessity in today's globalized system. If regulations in a country diverge too much from international best practices, as embodied for instance in the Basel Core Principles for Effective Banking Supervision, or if supervisory practices are too weak or burdened by government interference, investors-both domestic and foreign-might turn their backs on these countries, which then would be cut off from the benefits that foreign participation in the financial sector brings for economic development. Goodhart (1998, p.104-106) argues that work by the IFIs has had a beneficial impact on lasting improvements on the regulatory side. To have a similar impact on the actual supervisory practice is more difficult, however.

\footnotetext{
${ }^{35}$ One problem with empirical work in this area is that there are only a few independent agencies to use as control group.

${ }^{36}$ Moser (1999) comes to the conclusion that the effectiveness of central bank independence is higher in the OECD countries than in most other countries. Given that financial regulatory independence is worldwide even more in its infancy than central bank independence, such results indicate that effective agency independence is still some way off.
} 


\section{Political Control, Governance, and Accountability}

\section{Political accountability}

One of the recurring concerns about the concept of independent regulatory agencies is that it appears to involve the delegation of power without the mechanisms to hold unelected officials responsible for its exercise. A key issue is that it is not easy to fit this new type of institution into traditional constitutional frameworks, particularly in countries where the diffraction of state power is seen as a direct challenge to parliamentary sovereignty or to the principle of separation of powers. The reference made earlier to the fourth branch of government, in the minds of several authors, states the dilemma in quite simple terms: either the regulatory agency is part of the state administration and then it cannot be independent; or it is independent, but in that case to whom is it accountable? $?^{37,38}$

This dilemma rests on a misunderstanding of the nature of agency independence. Properly designed independence arrangements must include mechanisms for holding the agency accountable for the discharge of its functions without creating opportunities for ad hoc interference with its operations. ${ }^{39}$ Although the issue of proper accountability is far from resolved, mainly because the concept of an independent regulatory agency itself is still not universally accepted, groundbreaking work in terms of political accountability has been done in the context of central bank independence in the past two decades. ${ }^{40}$

\footnotetext{
${ }^{37}$ Some countries with recently rewritten constitutions--such as the transition economies from Central and Eastern Europe - - have the independence of the central bank stated in the constitution.
}

${ }^{38}$ The political control literature has a long history in the United States, because the concept of regulatory agencies goes further back in history than in Europe and the rest of the world. However, the main focus is mainly whether politicians have control over the work of their bureaucracies and to what extent? The issue of accountability has appeared more recently in the context of independent agencies. For overviews of the different strands in this literature, see for instance Epstein and O'Halloran (1999), Laffont and Tirole (1990), Majone (1993), and Steunenberg (1996).

${ }^{39}$ There is a tendency in the literature to picture the issue as a "trade-off between independence and accountability." This seems to us a misrepresentation of the issue. The two concepts need to be seen as complementary. Accountability is needed to make independence work. The higher the degree of independence, the more accountability arrangements are needed.

${ }^{40}$ Political accountability is receiving increasing attention from international fora. See for instance OECD (2000). The IMF Code of Good Practices in Transparency of Monetary and Financial Policies also pays a great deal of attention to accountability issues of central banks and regulatory agencies. 
Worldwide evidence suggests that independent regulators do not behave as an irresponsible or headless fourth branch. One of the currently prevailing theoretical models on the interaction between political authorities and independent regulatory agencies is the "dialogue model"--largely inspired by the agency theory and the new institutionalism-which supports the view that regulators (even statutory independent ones) do their best to be informed about the intentions, wishes, and opinions of the political leadership and to anticipate their reactions to new policy proposals (Majone, 1993). In other words, the model indicates that independent regulatory agencies are subject to some form of political control-almost selfimposed censorship.

Reassuring though this view is, many authors rightly see it as too informal and want to supplement it with other arrangements, in order to formalize the relationship. They try to meet the need for formal accountability by favoring a larger role for the courts in controlling agency discretion through procedural and substantive review of rule-making (Majone, 1993). While such partnership with the judicial branch is in principle good and protects the independence of the regulators, it still leaves the key issue of political accountability unanswered because the judicial branch is also independent and, as such, does not represent the legislative branch.

The search for mechanisms to avoid regulatory failures is, therefore, still on the agenda. Setting up proper channels for accountability requires walking a fine line between preserving the advantages of independence-continuity, coherence, and expertise-and giving too much attention to political expediency. Accountability needs to ensure that independent regulators (a) communicate with other political institutions and functions; (b) avoid the trap of industry capture or self-interest; (c) do not create new institutional rigidities; ${ }^{41}$ (d) avoid the tendency of over-regulation that may lead to additional costs for the industry; (e) do not slow down structural adjustment in the sector; and (f) evolve as competition emerges and evolves.

The need for adequate accountability arrangements is even more important for financial sector supervisory agencies than for regulators in other sectors, and perhaps even more than for central banks. This is because bank supervisors have considerable powers in two respects (Goodhart, 1998, p. 68): they affect the outcome for financial firms and they can have a significant impact on consumer welfare. On the other hand, the need for accountability should be balanced with another need inherent in the supervisory work, confidentiality. The presence of the latter aspect, as an inherent part of the supervisory function, makes the search for proper accountability and transparency arrangements very difficult. ${ }^{42}$

${ }^{41}$ In this context it has been argued that in those sectors where natural monopolies are eroding such as telecommunications and transport, the independent regulator will become redundant once these monopolies disappear (OECD, 2000). This argument does not seem to apply to financial sector regulation and supervision.

${ }^{42}$ See on this topic, Goodhart (2001). 


\section{Accountability arrangements}

Independent regulatory agency exercise powers delegated to it by the legislature and democratic legitimacy demands that the agency be accountable for the way it exercises those powers. Given the above list of diverse and complex issues, Majone (1993) argues that political accountability can only be achieved by a combination of approaches: "[A] highly complex and specialized activity like regulation can be monitored and kept politically accountable only by a combination of control instruments: legislative and executive oversight, strict procedural requirements, public participation, and, most importantly, substantive judicial review." In many countries, this mix has not yet been achieved. ${ }^{43}$

The ideal arrangement is, therefore, for an agency that scores highly across all four of the dimensions outlined in the preceding section, to balance its independence by solid measures of accountability. Establishing this delicate balance could be based on the following nine criteria.

\section{Legal basis}

The agency needs to have a clear legal basis, describing its powers and functions, and preferably set out in statute. A clear legal basis will preempt the potential for disputes between the agency and other government agencies or the court system. The appendix lists some examples where the enabling legislation (banking law and/or law establishing the supervisory agency) is vague about the regulatory powers of the supervisory agencies. ${ }^{44}$

\section{Objectives}

The agency needs to have clear objectives that describe its basic purposes. These can be preserving stability of the financial system and soundness of individual institutions; protection of depositors or of customers in general. Wilson (1989) emphasizes that successful organizations tend to have a well-defined mission. As such, this finding is important in the debate on the best location of the supervisory agency (inside or outside the central bank). Indeed, potential conflict of interest may blur the mission of both institutions and reduce their

\footnotetext{
${ }^{43}$ Majone (1993) remarks that, judged against these standards, regulation in Europe is seen as highly discretionary, suffering from weak accountability to parliament, weak judicial review, absence of procedural safeguards and insufficient public participation.

${ }^{44}$ For instance in many cases, supervisory agencies can issue "guidelines," but the legal character of these guidelines is not always clear. Supervisors might see them as binding, while other market participants consider them nonbinding. Such situations are bound to lead to confusion and protracted debates in case of banking problems. IMF (2001) discusses the case of Finland, where lawyers in the government and in the supervisory agency have different opinions about the scope of the supervisory agency's legal powers.
} 
accountability and effectiveness. In several countries, supervisory authorities have issued a "mission statement" clearly outlining the agency's specific objectives. This public document protects the agency against claims by the politicians as well as the supervised institutions that the mandate has not been followed and, as such, is a crucial element of accountability.

\section{Relationship with the executive}

The agency's relationship with the executive needs to be clearly defined, for example the range of issues on which, and the form in which, the agency must inform or consult the ministry of finance or seek ministerial approval should be spelled out.

\section{Appointment, reappointment, and dismissal procedures}

Officials of the regulatory agency must have security of tenure. By the same token, the ability to dismiss officials is also a key element of accountability. The law should stipulate who can appoint and dismiss senior officials and under what conditions. For supervisory agencies located in the central bank, the way the supervisory agency (department) relates to the management of bank needs proper attention. In many cases the governor of the central bank bears final responsibility for supervisory actions; in other cases the head of the supervisory agency does. Procedures for appointment, dismissal, and accountability of the head of the supervisory department need to be clearly defined.

\section{Override mechanisms}

While rule-based procedures are generally preferable to discretionary ones, there may be circumstances in which the independence of the agency has to be overridden (e.g., as the result of financial crisis). The nature of these override mechanisms and the circumstances in which they can be triggered need to be defined.

\section{Relationship with parliament}

The regulatory agency discharges functions that have been delegated to it by parliament, often of a quasi-legislative nature. The procedures by which the agency can be held to account by parliament for the use of those powers should be carefully defined.

\section{Relationship with judiciary}

The agency should be subject to judicial review with respect to the manner in which it exercises its powers. The existence of an appeals mechanism helps ensure that regulatory and supervisory decisions are made consistently and are well reasoned. Without a formal appeals mechanism, those affected by regulatory decisions may resort to informal means, especially by seeking to influence regulators by subjecting them to political pressure. As indicated earlier, the appeal mechanisms need to be clearly specified and balanced to preserve independence and effectiveness of supervisory action. 


\section{Transparency}

A regulatory agency needs to be open in its decision-taking procedures to the maximum extent permitted by the need to preserve commercial confidentiality. Transparency in the supervisory process serves several purposes: (a) it limits self-interest on the part the supervisors (the Kane-criticism) and the danger for regulatory capture. As such, disclosure of supervisory findings (and actions) is a way of letting market participants assess the effectiveness of supervision; (b) it discourages political interference in the supervisory process; and (c) it is also instrumental in increasing the commitment of bank managers, directors, and owners to prudent behavior and risk control of the banking business. ${ }^{45,46}$

\section{Budgetary accountability}

The regulatory agency must be held to account for the way that it manages its finances. This may be either ex ante (in the form of the budgetary appropriations process) or ex post (in the form of a review of the accounts.)

\section{Conclusions}

Despite its importance, the issue of independence for financial sector regulatory and supervisory authorities has only received marginal attention in the literature and in practice. In this paper, we attempted to fill this void. The paper argues that a fair degree of RSIcomplemented by appropriate accountability measures-is an essential building block of financial stability, as it is also recognized in the Basel Core Principles for Effective Banking Supervision. The paper makes the case that RSI and CBI reinforce each other in achieving monetary and financial stability.

A wide range of highly varying arrangements in terms of autonomy and accountability of supervisory agencies exists the world over. Lack of proper independence from political influence has been mentioned as an important contributing factor in all recent systemic banking crises, including Venezuela (1994), the East-Asian crisis countries (1997-98), and Turkey (2000). Hence the need to reflect upon methods to achieve independence for the regulatory and supervisory function.

\footnotetext{
${ }^{45}$ See also Halme (2001). Halme also discusses the need for, and difference between ex ante and ex post disclosure practices. She notes that supervisory agencies with well-established disclosure procedures (such as the FSA in the United Kingdom) typically have ex post disclosure requirements. Ex ante disclosure requirements are recognized to be more problematic since such disclosure can create more ambiguity and problems that it resolves.

${ }^{46}$ The IMF Code of Good Practices on Transparency of Monetary and Financial Policies should in this context serve as a important vehicle in promoting good regulatory governance.
} 
The case for RSI in the financial sector is based on analogies with two areas where agency independence has already been largely debated and established-the regulation of public utilities and central bank independence. With respect to the first, empirical work suggests that regulatory independence - accompanied by solid accountability--in general leads to better results in terms of more effective regulation, along with improved market behavior and competition than when leaving the regulatory and supervisory process to the political arena. Second, given the special nature of financial sector supervision, the paper draws on the arguments now well established in relation to CBI and argues that the independence of regulatory agencies matters from the point of view of financial stability for many of the same reasons that the independence of central banks makes a difference for monetary stability.

To make the concept of RSI operational, the paper sets out four dimensions of independence-regulatory, supervisory, institutional, and financial. While all four dimensions are important for the effectiveness of the regulatory and supervisory function, we emphasize that (a) autonomy in terms of setting prudential rules and regulations is a crucial requirement from all points of view; and (b) compared to other regulatory agencies, supervisory independence is highly desirable in light of the specific public good function that financial stability fulfills. However, achieving and preserving supervisory integrity requires a welldefined and high degree of transparency.

Experience indicates that arrangements for agency independence, by and of themselves, are necessary but not sufficient conditions for effective regulation and supervision. Institutional arrangements also matter. The paper reviews first the arguments in favor of and against housing the supervisory function in the central bank, as well as the recent tendency to integrate sector supervisory functions. It is recognized that RSI could benefit from the established central bank independence and from the fact that several central banks have received regulatory powers in their charters. On the other hand, conflict of interest and the danger of reputational damage are arguments against having supervision in the central bank. Moreover, placing an integrated supervisory agency in the central bank may make the latter too powerful and perhaps lead to too many conflicting objectives for one institution that would undermine its effectiveness. In any case, such an arrangement would require very clear accountability rules.

Subsequently the paper emphasizes-based on recent insights in the effectiveness of central bank independence-the need for checks and balances in the government system as a precondition for effective independence. The fewer checks and balances there are, the easier and less costly it is for the authorities to override or undermine agency independence. Given that a vast number of countries still lack a well-established system of political checks and balances, the paper points out that ways need to be identified to convince governments of the importance of not meddling with the financial sector, for growth, development, and stability purposes. Assessments of compliance with the Basel Core Principles for Effective Supervision and of observance with the Code on Good Practices in Transparency of Monetary and Financial Policies could be instrumental in this regard, but interference in the supervisory work can be so subtle that it is hard to stop. 
Recognizing that the key to effective regulation and supervision is not absolute independence, the paper contends that adequate accountability arrangements should complement independence. Although worldwide evidence suggests that independent agencies do not behave as an uncontrolled "fourth branch of government," unbalanced independence may open the door to industry capture or self-interest; the creation of new institutional rigidities; over-regulation, leading to additional costs for the industry; a slowdown in structural adjustment in the sector; and lack of communication with other layers of government. Given these potential traps, a highly complex and specialized activity like banking regulation and supervision requires a combination of control instruments. This makes accountability the single most important factor to make independence work.

The paper suggests a set of arrangements to ensure proper accountability for regulatory agencies, covering: the agency's legal basis; the definition of clear objectives; procedures for appointment, reappointment, and dismissal; override mechanisms; the relationship with the executive branch, parliament, and the judiciary; and arrangements for transparency and for budgetary accountability. Implementation and proper execution of these methods, with special attention to transparency arrangements, should ensure that independence and accountability are properly balanced, leading to more efficient and effective regulation and supervision of the sector, as a contribution to overall financial sector stability.

Using the four dimensions of independence and the nine criteria for accountability, inspection of the selected country list in the appendix indicates that arrangements in Australia, Belgium, Bolivia, Colombia, the United Kingdom and the United States come closest to the ideal model. However, these preliminary impressions should be treated with caution and more analysis of the institutional arrangements is needed. For instance, it should be emphasized that the appendix did not identify any yardstick to measure independence of the supervisory function. Second, some agencies may de facto operate more independently than the prima facie arrangements seem to indicate. An encouraging sign is that recently reformed agencies have more features of agency independence than their predecessors. Nevertheless, we are still a long way from the ideal situation. 


\section{Bibliography}

Abrams, Richard K and Michael W. Taylor (2000). "Issues in the Unification of Financial Sector Supervision," IMF Working Paper 00/213.

Alesina, Alberto and Lawrence H. Summers (1993), "Central Bank Independence and Macroeconomic Performance: Some Comparative Evidence," Journal of Money, Credit, and Banking, Vol. 25, No. 2, p. 151-162.

Barth, James, Gerard Caprio, and Ross Levine (2001), "The Regulation and Supervision of Banks around the World: A New Database," p. 183-250, in Robert Litan and Richard Herring, Brookings-Wharton Papers on Financial Services, (Washington DC: Brookings Institution Press).

Basel Committee on Banking Supervision (1997), "Core Principles for Effective Banking Supervision," Basel Committee on Banking Supervision, No. 30, September (Basel: Bank for International Settlements).

Boot, Arnoud W.A., and Anjan V. Thakor (1993), "Self-Interested Bank Regulation," American Economic Review, Vol. 83, No. 2, p. 206-212.

Brealey, Richard, Alastair Clark, Charles Goodhart, Juliette Healey, Glenn Hoggarth, David T. Llewellyn, Chang Shu, Peter Sinclair, Farouk Soussa (2001), "Financial Stability and Central Banks. A Global Perspective." Central Bank Governors' Symposium Series, Routledge, London.

Calomiris, Charles and Robert Litan (2000), "Financial Regulation in a Global Marketplace," p. 283-340, in Robert Litan and Anthony Santomero, (eds), Brookings-Wharton Papers on Financial Services, (Washington DC: Brookings Institution Press).

Courtis, Neil (ed., 2001), "How Countries Supervise Their Banks, Insurers, and Securities Markets 2002," (London: Central Banking Publications), p.266.

Crockett, Andrew, (1997), "Why is Financial Stability a Goal of Public Policy," Federal Reserve Bank of Kansas City, Fourth Quarter.

Cukierman, Alex, Steven B. Webb, and Bilin Neyapti (1992), "Measuring The Independence of Central Banks and its Effect on Policy Outcomes," World Bank Economic Review (International), vol. 6, p. 353-98.

De Krivoy, Ruth (2000), Collapse. The Venezuelan Banking Crisis of 1994, (Washington D.C.: The Group of Thirty). 
Delston, Ross (1999), Statutory Protections for Banking Supervisors, The World Bank, Financial Sector Group.

Eijffinger, Sylvester C.W. and Jakob de Haan (1996), The Political Economy of Central Bank Independence, International Finance Section, Department of Economics, Princeton University.

Enoch, Charles, Barbara Baldwin, Olivier Frécaut, and Arto Kovanen (2001), "Indonesia: Anatomy of a Banking Crisis. Two Years of Living Dangerously 1997-99," $I M F$ Working Paper WP/01/52.

Epstein, David and Sharyn O'Halloran, 1999, Delegating Powers: A Transaction Cost Politics Approach to Policy Making Under Separate Powers, New York, Cambridge University Press.

Fischer, Stanley (1995), Central Bank Independence Revisited, American Economic Review, Papers and Proceedings, Vol. 85, 201-206, May.

Franzese, Robert, Jr. (1999), "Partially Independent Central Banks, Politically Responsive Governments and Inflation," American Journal of Political Science, Vol. 43, No. 3, p. $681-706$.

Goodhart, Charles (2000), "The Organizational Structure of Banking Supervision," paper presented at the Conference "Financial Supervision of Banks and Specialized Banks in the EU" European University Institute, December.

—_, (2001), "Regulating the Regulators - Accountability and Control," p. 151-164, in E. Ferran and C.A.E. Goodhart (ed), "Regulating Financial Services and Markets in the $21^{\text {st }}$ Century," Hart Publishing, Oxford, UK.

—, (ed, 1998), "The Emerging Framework of Financial Regulation," a collection of papers compiled by the Financial Markets Group of the London School of Economics (London: Central Banking Publications Ltd.).

___ Philipp Hartmann, David Llewellyn, Liliana Rojas-Suarez, and Steven Weisbrod (1998), "Financial Regulation. Why, how and where now?" Routledge, London, and New York.

Goodhart, Charles and Dirk Schoenmaker (1998), "Institutional Separation Between Supervisory and Monetary Agencies," reprinted p. 133-212, in C.A.E., Goodhart (ed), "The Emerging Framework of Financial Regulation" Central Banking Publications, London. 
Grilli, V., D. Masciandaro, and G. Tabellini, (1991), "Political and Monetary Institutions and Public Financial Policies in the Industrial Countries," Economic Policy, 13, p. 342-392.

Gros, Daniel and Niels Thygesen (1992), European Monetary Integration, Harlow, Essex ; New York, Longman.

Halme, Liisa (2000), "Bank Corporate Governance and Financial Stability," in Liisa Halme, Christian Hawkesby, Juliette Healey, Indrek Saapar, and Farouk Soussa "Financial Stability and Central Bank. Selected Issues for Financial Safety Nets and Market Discipline," (London: Bank of England. Centre for Central Banking Studies) p.130.

Hartcher, Peter (1998), The Ministry: How Japan's Most Powerful Institution Endangers World Markets, Harvard Business School Press.

Hayward, Peter (2002), "The Financial Sector-The Responsibilities fo the Public Agencies," in Charles Enoch, David Marston, and Michael Taylor, Financial Sector Surveillance and Resolution, (IMF: Washington, D.C., forthcoming).

Hawkesby, Christian (2001), "Central Banks and Supervisors: The Question of Institutional Structure and Responsibilities," in Liisa Halme, Christian Hawkesby, Juliette Healey, Indrek Saapar, and Farouk Soussa, Financial Stability and Central Bank. Selected Issues for Financial Safety Nets and Market Discipline (London: Bank of England. Centre for Central Banking Studies), p.130.

Healey, Juliette (2001), "Financial Stability and the Central Bank: international evidence," p. 19-78, in Brealey, Richard, and others, "Financial Stability and Central Banks. A Global Perspective." Central Bank Governors' Symposium Series, Routledge, London.

International Monetary Fund (1999), Code of Good Practices on Transparency of Monetary and Financial Policies, September (Washington, D.C., International Monetary Fund).

International Monetary Fund (2001), Finland: Financial System Stability Assessment. Country Report No 01/214.

Jacobs, Scott (1999), "The Second Generation of Regulatory Reforms," paper delivered at the IMF Conference on Second Generation Reforms, available at the IMF website.

Kane, Edward (1990), "Principal-Agent Problems in S\&L Salvage," Journal of Finance, Vol. 45, July, 755-764. 
Keefer, Philip (1999), "Politics and the Determinants of Banking Crises: The Effects of Political Checks and Balances on the Dynamics of Financial Sector Distress," World Bank Development Research Group, paper presented at the meeting of the Western Economics Association, July.

_._. and David Stasavage (2001), "Bureaucratic Delegation and Political Institutions: When Are Independent Central Banks Irrelevant?" World Bank Discussion Paper.

Kydland, Finn and Edward Prescott (1977) "Rules Rather than Discretion: The Inconsistency of Optimal Plans" Journal of Political Economy, 85, 3, p. 473-491.

Laffont, Jean-Jacques, and David Martimont (1999), "Separation of Regulators Against Collusive Behavior," RAND Journal of Economics, Vol. 30, No. 2, p. 232-262.

Laffont, Jean-Jacques, and Jean Tirole (1990), "The Politics of Government Decision Making: Regulatory Institutions," Journal of Law, Economics and Organization, Vol.6, No. 1, p. 1-31.

Lastra, Rosa Maria, 1996, Central Banking and Banking Regulation, (London: LSE, Financial Markets Group) p. 392.

Central Banking, Vol X, No. 3, p 34-39.

Lindgren, Carl-Johan, Tomas J.T. Baliño, Charles Enoch, Anne-Marie Gulde, Marc Quintyn, and Leslie Teo (1999), "Financial Sector Crisis and Restructuring. Lessons from Asia," IMF Occasional Paper 188 (Washington D.C. International Monetary Fund).

Macey, Jonathan and Miller, Geoffey, 1997, Banking Law and Regulation, New York, Aspen Law and Business.

Majone, Giandomenico (1993), "Controlling Regulatory Bureaucracies: Lessons from the American Experience, EUI Working Paper SPS 93/3.

Marquardt, Jeffey (1987), "Financial Market Supervision: Some Conceptual Issues," BIS Economic Papers, No. 10, May, Bank for International Settlements, Basel.

McCubbins, Matthew D., Roger G. Noll, and Barry R. Weingast (1987), "Administrative Procedures as Instruments of Political Control, Journal of Law, Economics, and Organization, Vol. 3, No. 2.

Moser, Peter, 1999, "Checks and Balances and the Supply of Central Bank Independence," European Economic Review 43, 1569-1593. 
OECD, "Regulating Governance: Improving the Institutional Basis For Sectoral Regulation," Meeting of the Regulatory Management and Reform Working Party, OECD Headquarters, p. 4-5.

Quinn, Brian (1998), "Rules v Discretion: The Case for Banking Supervision in the Light of the Debate on Monetary Policy," p. 119-132 in, Goodhart, C.A.E. (ed.), The Emerging Framework of Financial Regulation, Central Banking Publications, London.

Rogoff, Kenneth (1985), "Optimal Degree of Commitment to an Intermediate Monetary Target: Inflation Gains Versus Stabilization Costs," Quarterly Journal of Economics, 100, November, 1169-89.

Steunenberg, Bernard (1996), “Agent Discretion, Regulatory Policy Making, and Different Institutional Arrangements," Public Choice, Vol. 46, p. 275-287.

Stigler, George (1971), "The Theory of Economic Regulation," Bell Journal of Economics and Management Science, Vol. 6, No. 2, p. 114-141.

Taylor, Michael, and A. Fleming (1999), "Integrated Financial Supervision: Lessons of Northern European Experience," World Bank Policy Research Paper No. 2223, November (Washington, D.C.: World Bank).

Vives, Xavier (2000a), "Central Banks and Supervision (with an application to financial architecture in EMU)," paper presented at the Conference "Financial Supervision of Banks and Specialized Banks in the EU," European University Institute, December.

Vives, Xavier (2000b), "Banking Supervision in the European Monetary Union," paper presented at the Conference "Financial Supervision of Banks and Specialized Banks in the EU," European University Institute, December.

White, Lawrence J. (1996), "On the International Harmonization of Bank Regulation," Oxford Review of Economic Policy, Vol. 10, No. 4.

"Wilson, J. Q. (1989), Bureaucracy: What Government Agencies Do and Why They Do It, New York, Basic Books.

Wood, Dan and Richard Waterman (1991), "The Dynamics of Political Control of the Bureaucracy," American Political Science Review, Vol. 85, No. 3, 801-828. 
Overview of Features of Autonomy of Banking Supervisors in Selected Countries

\begin{tabular}{|c|c|c|c|c|c|}
\hline Country & $\begin{array}{l}\text { Name of Institution And } \\
\text { Sectoral Responsibilities }\end{array}$ & Regulatory Power & Budgetary Autonomy & $\begin{array}{l}\text { Appointment Of President } \\
\text { And Accountability }\end{array}$ & $\begin{array}{c}\text { Power To Grant And } \\
\text { Withdraw Licenses And } \\
\text { Specific Issues Related To } \\
\text { Degree Of Autonomy }\end{array}$ \\
\hline
\end{tabular}

\section{A. Countries where banking supervision is part of the central bank}

Czech

Republic

The Gambia

Banking Supervision

Department, Czech National

Bank (CNB)

Commercial banks, foreign

banks branches and persons

other than banks licensed under

separate Acts.

Banking and Financial

Institutions Supervision

Department, Central Bank of

the Gambia (CBG).

Commercial banks, insurance

companies and nonfinancial

institutions (micro-finance).

Ghana

Banking Supervision

Department (BSD), Bank of

Ghana (BOG).

Commercial, development,

merchant and rural banks.
CNB has the legal authority

to specify prudential

regulations within the

confines of the banking law.

Budget allocation made from the CNB.

The Board of the CBG has the power to make by-laws and issue directives to regulate the conduct of the Bank's business. With the approval of the minister the CBG can make regulations for the purpose to giving effect to the CB Act.

BSD functions include revisions of the banking legislation, drafting of prudential guidelines on the interpretation and applications of the banking laws.

Bank governor and vice governors (the Board) are appointed by the president. The head of banking supervision is appointed by the Board of Directors and is accountable to the Board.

Operating income of the CBG.

Bank of Ghana Budget.

The governor is appointed

by the government of

Ghana on the

recommendation of the minister of finance. The governor is the Chairman of the Board and accountable to the board.

The Board appoints the Head of the Banking Supervision Department.
The CNB needs to request the opinion of the minister of finance prior to granting or revoking a license.

CBG has the authority to grant and withdraw licenses

Licenses are issued and revoked by the BOG subject to the approval of the Secretary (an officer designated by the Board). 
Overview of Features of Autonomy of Banking Supervisors in Selected Countries

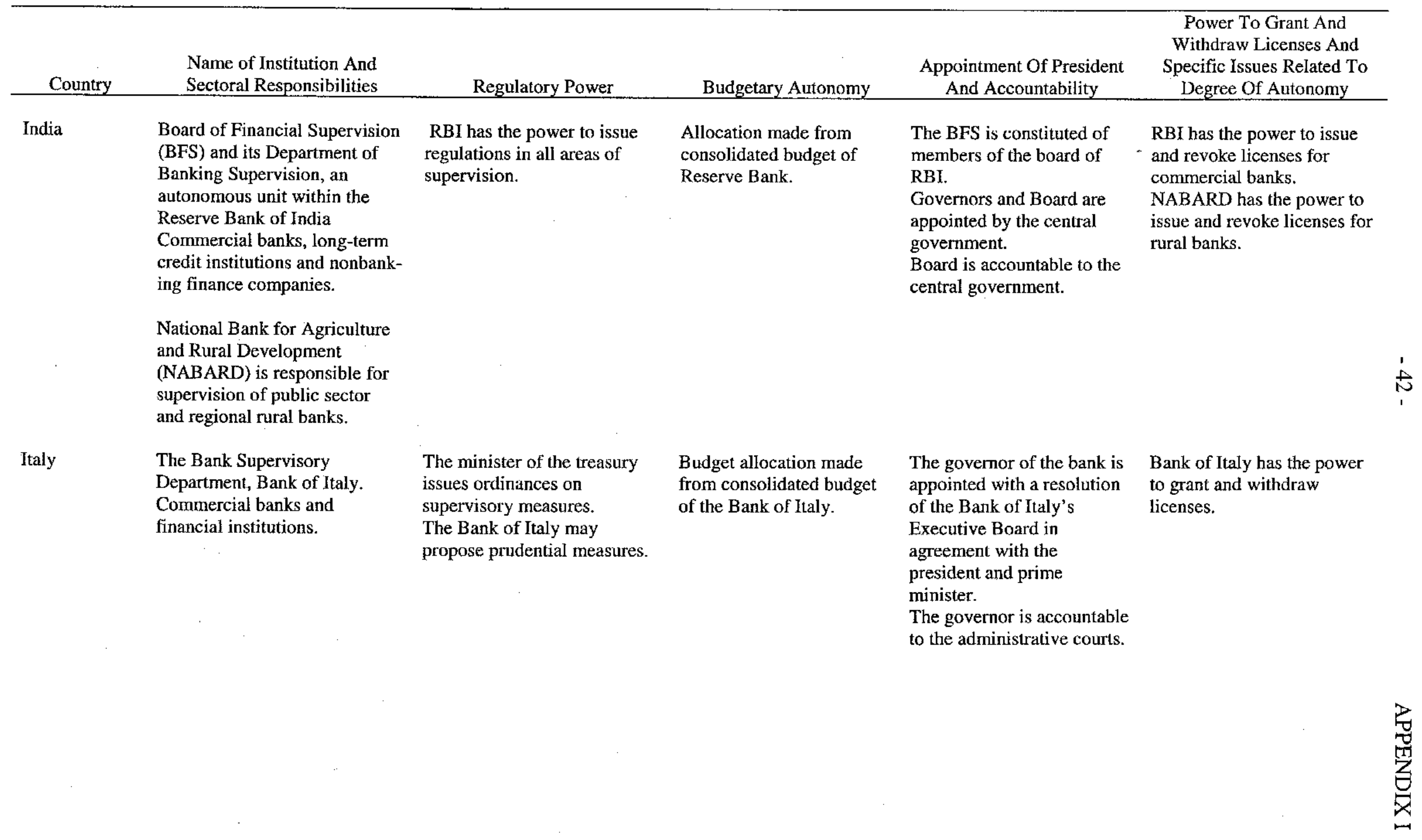


Overview of Features of Autonomy of Banking Supervisors in Selected Countries

\begin{tabular}{|c|c|c|c|c|c|}
\hline Country & $\begin{array}{l}\text { Name of Institution And } \\
\text { Sectoral Responsibilities }\end{array}$ & Regulatory Power & Budgetary Autonomy & $\begin{array}{l}\text { Appointment Of President } \\
\text { And Accountability }\end{array}$ & $\begin{array}{c}\text { Power To Grant And } \\
\text { Withdraw Licenses And } \\
\text { Specific Issues Related To } \\
\text { Degree Of Autonomy }\end{array}$ \\
\hline Kazakhstan & $\begin{array}{l}\text { Banking Supervision } \\
\text { Department, National Bank of } \\
\text { the Republic of Kazakhstan } \\
\text { (NBK). } \\
\text { Banks }\end{array}$ & $\begin{array}{l}\text { NBK is empowered to issue } \\
\text { resolutions and decrees in all } \\
\text { the key aspects of prudential } \\
\text { stipervision, including capital } \\
\text { adequacy, asset quality, } \\
\text { liquidity management, and } \\
\text { foreign exchange exposure. }\end{array}$ & NBK's budget. & $\begin{array}{l}\text { The Chairman of the NBK } \\
\text { is appointed by the } \\
\text { President upon approval by } \\
\text { the Parliament. } \\
\text { The Head of the Banking } \\
\text { Supervision Department is } \\
\text { appointed by the Chairman } \\
\text { of the NBK. }\end{array}$ & $\begin{array}{l}\text { NBK has the power to issue } \\
\text { and revoke licenses. } \\
\text { However, bank shareholders } \\
\text { have the ability to obtain } \\
\text { court orders overturning } \\
\text { decisions of the NBK. }\end{array}$ \\
\hline Malaysia & $\begin{array}{l}\text { Bank Supervision and Bank } \\
\text { Regulation Departments of } \\
\text { Bank Negara Malaysia (BNM) } \\
\text { Commercial banks, finance } \\
\text { companies, merchant banks, } \\
\text { discount houses and money } \\
\text { brokers. }\end{array}$ & $\begin{array}{l}\text { BNM's Board of Directors } \\
\text { can issue binding regulations. }\end{array}$ & $\begin{array}{l}\text { Central bank's budget. } \\
\text { BNM enjoys autonomy. }\end{array}$ & $\begin{array}{l}\text { Governor appointed by the } \\
\text { King, accountable to the } \\
\text { board of directors. }\end{array}$ & $\begin{array}{l}\text { Ministry of finance grants } \\
\text { and revokes licenses on the } \\
\text { recommendation of the } \\
\text { BNM. }\end{array}$ \\
\hline $\begin{array}{l}\text { The } \\
\text { Netherlands }\end{array}$ & $\begin{array}{l}\text { Banking Supervision } \\
\text { Department, the Nederlandsche } \\
\text { Bank (DNB). } \\
\text { Commercial banks. }\end{array}$ & $\begin{array}{l}\text { Within the confines of the } \\
\text { law on supervision, the DNB } \\
\text { has the power to issue } \\
\text { prudential regulations. } \\
\text { Banks are consulted when } \\
\text { drafting regulations. } \\
\text { In some cases, coordination } \\
\text { with the ministry of finance is } \\
\text { required. }\end{array}$ & $\begin{array}{l}\text { Supervisory budget comes } \\
\text { from fees levied on the } \\
\text { supervised instilutions. }\end{array}$ & $\begin{array}{l}\text { The president of the DNB is } \\
\text { appointed by royal decree. } \\
\text { The president is } \\
\text { accountable to the relevant } \\
\text { committees of parliament. }\end{array}$ & $\begin{array}{l}\text { DNB issues and revokes } \\
\text { licenses. }\end{array}$ \\
\hline Poland & $\begin{array}{l}\text { General Inspectorate of } \\
\text { Banking Supervision (GINB) } \\
\text { executive agency of the } \\
\text { Commission for Banking } \\
\text { Supervision (CBS), separate }\end{array}$ & $\begin{array}{l}\text { The GNBI has the power to } \\
\text { issue prudential regulations } \\
\text { for the banking system. }\end{array}$ & $\begin{array}{l}\text { Operating budget of the } \\
\text { NBP. }\end{array}$ & $\begin{array}{l}\text { Chair of CBS is the } \\
\text { president of the NBP who is } \\
\text { appointed by the lower } \\
\text { chamber of parliament at } \\
\text { the request of the president. }\end{array}$ & $\begin{array}{l}\text { The CBS, in agreement with } \\
\text { the minister of finance, } \\
\text { issues and revokes licenses. }\end{array}$ \\
\hline
\end{tabular}


Overview of Features of Autonomy of Banking Supervisors in Selected Countries

\begin{tabular}{|c|c|c|c|c|c|}
\hline Country & $\begin{array}{l}\text { Name of Institution And } \\
\text { Sectoral Responsibilities }\end{array}$ & Regulatory Power & Budgetary Autonomy & $\begin{array}{l}\text { Appointment Of President } \\
\text { And Accountability }\end{array}$ & $\begin{array}{c}\text { Power To Grant And } \\
\text { Withdraw Licenses And } \\
\text { Specific Issues Related To } \\
\text { Degree Of Autonomy }\end{array}$ \\
\hline & $\begin{array}{l}\text { entity in the National Bank of } \\
\text { Poland (NBP). } \\
\text { Commercial banks, cooperative } \\
\text { banks, and reprehensive offices } \\
\text { of foreign banks. }\end{array}$ & & & $\begin{array}{l}\text { In agreement with the } \\
\text { minister of finance, the } \\
\text { president of the NBP } \\
\text { appoints the general } \\
\text { inspector who becomes a } \\
\text { member of the commission } \\
\text { and leads the GINB. } \\
\text { General inspector is } \\
\text { accountable to the CBS and } \\
\text { to the NBP. }\end{array}$ & - \\
\hline $\begin{array}{l}\text { The } \\
\text { Philippines }\end{array}$ & $\begin{array}{l}\text { Supervision and Examination } \\
\text { Sector, Central Bank of the } \\
\text { Philippines (BSP). } \\
\text { Banks, finance companies and } \\
\text { nonbank financial institutions. }\end{array}$ & $\begin{array}{l}\text { The Monetary Board can } \\
\text { issue prudential rules of } \\
\text { conduct. }\end{array}$ & $\begin{array}{l}\text { The supervisory function } \\
\text { is funded from the BSP's } \\
\text { general budget as } \\
\text { approved by the Monetary } \\
\text { Board. This budget } \\
\text { includes examination fees } \\
\text { from supervisory } \\
\text { institutions. }\end{array}$ & $\begin{array}{l}\text { Governor and Monetary } \\
\text { Board are appointed by the } \\
\text { president. } \\
\text { The governor is accountable } \\
\text { to the Board. }\end{array}$ & $\begin{array}{l}\text { The BSP's Monetary Board } \\
\text { issues and revokes licenses. }\end{array}$ \\
\hline Saudi Arabia & $\begin{array}{l}\text { Banking Supervision } \\
\text { Department of Saudi Arabian } \\
\text { Monetary Agency (SAMA) } \\
\text { Commercial banks and } \\
\text { exchange dealers. }\end{array}$ & $\begin{array}{l}\text { SAMA with the approval of } \\
\text { the ministry of finance and } \\
\text { national economy has the } \\
\text { power to issue prudential } \\
\text { rules. }\end{array}$ & $\begin{array}{l}\text { Central bank's operating } \\
\text { income. }\end{array}$ & $\begin{array}{l}\text { Governor is appointed by } \\
\text { Royal Decree. Board of } \\
\text { Directors is appointed by } \\
\text { the government. } \\
\text { All are accountable to the } \\
\text { minister of finance. }\end{array}$ & $\begin{array}{l}\text { SAMA issues } \\
\text { recommendations to the } \\
\text { ministry of finance and } \\
\text { national economy to issue } \\
\text { and revoke licenses. }\end{array}$ \\
\hline South Africa & $\begin{array}{l}\text { Bank Supervision Department } \\
\text { (BSD), South African Reserve } \\
\text { Bank (SARB). } \\
\text { Banks and mutual funds. }\end{array}$ & $\begin{array}{l}\text { The minister of finance is } \\
\text { formally responsible for the } \\
\text { issue of regulations, and a } \\
\text { number of key operational } \\
\text { decisions (i.e., remedial } \\
\text { actions) require his approval. }\end{array}$ & $\begin{array}{l}\text { Own budget approved by } \\
\text { the governor, appropriated } \\
\text { from the general funds of } \\
\text { the SARB. }\end{array}$ & $\begin{array}{l}\text { Governor is appointed by } \\
\text { the president. } \\
\text { The registrar of banks is the } \\
\text { head of the BSD and is } \\
\text { appointed by the SARB } \\
\text { subject to approval by the } \\
\text { ministry of finance. }\end{array}$ & $\begin{array}{l}\text { The SARB is solely } \\
\text { responsible for licensing } \\
\text { banks. } \\
\text { In certain cases, specified in } \\
\text { the law, he has the power to } \\
\text { withdraw licenses. In other } \\
\text { cases, the approval of the }\end{array}$ \\
\hline
\end{tabular}


Overview of Features of Autonomy of Banking Supervisors in Selected Countries

\begin{tabular}{|c|c|c|c|}
\hline Country & $\begin{array}{l}\text { Name of Institution And } \\
\text { Sectoral Responsibilities }\end{array}$ & Regulatory Power & Budgetary Autonomy \\
\hline \multicolumn{3}{|c|}{ B. Countries where supervision is located in ministry of finance } & 3 \\
\hline Austria & $\begin{array}{l}\text { Federal ministry of finance } \\
\text { (FMF) } \\
\text { All domestic banks and } \\
\text { branches of foreign banks. }\end{array}$ & $\begin{array}{l}\text { The FMF is the sole issuer of } \\
\text { rules and regulations. }\end{array}$ & $\begin{array}{l}\text { The budget for supervision } \\
\text { is part of the FMF budget. } \\
\text { Fees from the industry are } \\
\text { used for specific occasions } \\
\text { (like the appointment of a } \\
\text { state commissioner for a } \\
\text { specific bank). }\end{array}$ \\
\hline
\end{tabular}

\section{Countries where supervision is a separate agency}

Australia

$$
\begin{aligned}
& \text { Australian Prudential } \\
& \text { Regulation Authority (APRA). } \\
& \text { Authorized deposit taking } \\
& \text { institutions (ADIs) including } \\
& \text { nonoperating holding } \\
& \text { companies of ADIs (NOHC). }
\end{aligned}
$$

APRA has power to issue prudential standards for ADIs and NOFICs.
The source of funding is an industry levy paid into consolidated revenue.
The minister of finance has ultimate responsibility in

supervisory matters.

Registrar is accountable to the central bank governor (operationally) and to the minister of finance.
Appointment Of President Specific Issues Related To Degree Of Autonomy
The FMF, as the supervisory authority has the sole power to grant and withdraw

\section{licenses.}

The recently revised banking act has provided the Austrian National Bank (ON) with some supervisory duties. The ON can be called upon to carry on-site audits in specific cases or to prepare expert opinions for the FMF.

CEO and Board members are appointed by the

APRA grants and revokes licenses.

treasurer and are

accountable to the

commonwealth parliament. 


\section{Overview of Features of Autonomy of Banking Supervisors in Selected Countries}

\begin{tabular}{|c|c|c|c|c|c|}
\hline Country & $\begin{array}{l}\text { Name of Institution And } \\
\text { Sectoral Responsibilities }\end{array}$ & Regulatory Power & Budgetary Autonomy & $\begin{array}{c}\text { Appointment Of President } \\
\text { And Accountability }\end{array}$ & $\begin{array}{c}\text { Power To Grant And } \\
\text { Withdraw Licenses And } \\
\text { Specific Issues Related To } \\
\text { Degree Of Autonomy }\end{array}$ \\
\hline Belgium & $\begin{array}{l}\text { Commission for Banking and } \\
\text { Finance (CBF) } \\
\text { Commercial banks and capital } \\
\text { market operators. }\end{array}$ & $\begin{array}{l}\text { The Banking Law empowers } \\
\text { the CBF to issue prudential } \\
\text { regulations. }\end{array}$ & $\begin{array}{l}\text { CBF's budget is funded by } \\
\text { fees on financial market } \\
\text { operations and charges on } \\
\text { registered credit } \\
\text { institutions and investment } \\
\text { firms. However, its size is } \\
\text { determined by the ministry } \\
\text { of finance. }\end{array}$ & $\begin{array}{l}\text { President is appointed by } \\
\text { the government. He } \\
\text { presents the annual report to } \\
\text { the parliamentary } \\
\text { commission for financial } \\
\text { matters (this is a practice } \\
\text { introduced by the CBF } \\
\text { president, but not stipulated } \\
\text { in the law). }\end{array}$ & $\begin{array}{l}\text { CBF has full autonomy in } \\
\text { granting and withdrawing } \\
\text { licenses. }\end{array}$ \\
\hline Bolivia & $\begin{array}{l}\text { Superintendency of Banks and } \\
\text { Financial Entities (SBEF). } \\
\text { Financial institutions. }\end{array}$ & $\begin{array}{l}\text { The SBEF is empowered to } \\
\text { draft and implement } \\
\text { prudential regulations. }\end{array}$ & $\begin{array}{l}\text { All financial entities pay } \\
\text { an annual fee according to } \\
\text { their total assets. }\end{array}$ & $\begin{array}{l}\text { Superintendent is appointed } \\
\text { by the President of the } \\
\text { Republic. } \\
\text { The superintendent is } \\
\text { accountable to the minister } \\
\text { of finance. }\end{array}$ & $\begin{array}{l}\text { Licensing authorily is the } \\
\text { SBEF. }\end{array}$ \\
\hline Canada & $\begin{array}{l}\text { Office of the Superintendent of } \\
\text { Financial Institutions (OSFI) } \\
\text { Banking, insurance, nonbank } \\
\text { deposit taking institutions. }\end{array}$ & $\begin{array}{l}\text { OSFI derives its power } \\
\text { largely from the OSFI Act } \\
\text { (1997). } \\
\text { Within the constraints of that } \\
\text { Act, OSFI issues guidelines, } \\
\text { policy statements, and } \\
\text { bulletins to provide additional } \\
\text { guidance to supervised } \\
\text { institutions. }\end{array}$ & $\begin{array}{l}\text { Asset or premium based } \\
\text { assessments and } \\
\text { supplementary user pay } \\
\text { assessments. }\end{array}$ & $\begin{array}{l}\text { The superintendent reports } \\
\text { directly to the minister of } \\
\text { finance. The minster of } \\
\text { finance officially hcads the } \\
\text { OSFI and, thus, carries } \\
\text { ultimate responsibility. The } \\
\text { superintendent is given a } \\
\text { degree of operational } \\
\text { independence, however, } \\
\text { s/he maybe removed from } \\
\text { the office for just cause by } \\
\text { the Governor-in-Council. }\end{array}$ & $\begin{array}{l}\text { The minister of finance is } \\
\text { responsible for granting and } \\
\text { revoking licenses. } \\
\text { The OSFI is considered as } \\
\text { an independent authority in } \\
\text { supervisory matters, but the } \\
\text { ministry of finance is } \\
\text { heavily involved at the } \\
\text { policy level. It may reverse } \\
\text { actions of the OSFI, } \\
\text { including the taking control } \\
\text { over institutions. }\end{array}$ \\
\hline
\end{tabular}


Overview of Features of Autonomy of Banking Supervisors in Selected Countries

\begin{tabular}{|c|c|c|c|c|c|}
\hline Country & $\begin{array}{l}\text { Name of Institution And } \\
\text { Sectoral Responsibilities }\end{array}$ & Regulatory Power & Budgetary Autonomy & $\begin{array}{c}\text { Appointment Of President } \\
\text { And Accountability }\end{array}$ & $\begin{array}{c}\text { Power To Grant And } \\
\text { Withdraw Licenses And } \\
\text { Specific Issues Related To } \\
\text { Degree Of Autonomy }\end{array}$ \\
\hline Chile & $\begin{array}{l}\text { Superintendency of Banks and } \\
\text { Financial Institutions (SBIF) } \\
\text { Banco del Estado, banks, } \\
\text { financial institutions and } \\
\text { companies issuing or operating } \\
\text { credit cards or similar systerns. }\end{array}$ & $\begin{array}{l}\text { The Central Bank of Chile } \\
\text { has the authority to issue } \\
\text { prudential regulations. The } \\
\text { SBIF carries out inspection } \\
\text { and supervision. }\end{array}$ & $\begin{array}{l}\text { Superintendency is funded } \\
\text { from fees from supervised } \\
\text { entities }\end{array}$ & $\begin{array}{l}\text { Superintendent is appointed } \\
\text { by President of the } \\
\text { Republic. } \\
\text { SBIF is subject to control of } \\
\text { the Republic's Comptroller } \\
\text { Office with respect to all } \\
\text { aspects related to the } \\
\text { examination of its accounts. }\end{array}$ & $\begin{array}{l}\text { SBIF issues and revokes } \\
\text { licenses. }\end{array}$ \\
\hline Colombia & $\begin{array}{l}\text { Banking Superintendence of } \\
\text { Colombia (SBC). } \\
\text { Credil institutions, financial } \\
\text { services, and other financial } \\
\text { companies. }\end{array}$ & $\begin{array}{l}\text { SBC has the power to issue } \\
\text { rules and regulations and take } \\
\text { corrective action. }\end{array}$ & $\begin{array}{l}\text { Fee paid by supervised } \\
\text { institutions. }\end{array}$ & $\begin{array}{l}\text { The SBC and members of } \\
\text { its advisory council are } \\
\text { directly appointed by the } \\
\text { President of the Republic. }\end{array}$ & $\begin{array}{l}\text { Licensing authority is the } \\
\text { SBC. }\end{array}$ \\
\hline France & $\begin{array}{l}\text { Banque de France (BdF) } \\
\text { Banking Regulation } \\
\text { Commitlee (CRBF) } \\
\text { Banking Commission. } \\
\text { The Credil Institutions and } \\
\text { Investment Service Provider's } \\
\text { Committee (CECEI). } \\
\text { All credit institutions and } \\
\text { investment firms. }\end{array}$ & $\begin{array}{l}\text { Regulatory power lies with a } \\
\text { committee consisting of } \\
\text { representatives from Banque } \\
\text { de France, ministry of } \\
\text { finance, supreme court and } \\
\text { banking industry (CRBF and } \\
\text { CECEI). } \\
\text { Updating the regulatory } \\
\text { framework is te facto driven } \\
\text { by the Secretariat of Banking } \\
\text { Commission. }\end{array}$ & $\begin{array}{l}\text { Funding comes from the } \\
\text { Banque de France. Until } \\
\text { 1993, the Secretariat of the } \\
\text { Banking Commission was } \\
\text { a department of the BdF. } \\
\text { Now it is a separate } \\
\text { administrative entity. } \\
\text { Since BdF is budgetary } \\
\text { independent, Banking } \\
\text { Commission is too. }\end{array}$ & $\begin{array}{l}\text { Head of Secretariat is } \\
\text { appointed by minister of } \\
\text { finance. } \\
\mathrm{He} \text { is accountable to the } \\
\text { minister, but in practice to } \\
\text { the governor of the BdF, } \\
\text { who is the chairman of the } \\
\text { Banking Commission. }\end{array}$ & $\begin{array}{l}\text { The CECEI issues and } \\
\text { revokes licenses. }\end{array}$ \\
\hline
\end{tabular}


Overview of Features of Autonomy of Banking Supervisors in Selected Countries

\begin{tabular}{|c|c|c|c|c|c|}
\hline Country & $\begin{array}{l}\text { Name of Institution And } \\
\text { Sectoral Responsibilities }\end{array}$ & Regulatory Power & Budgetary Autonomy & $\begin{array}{l}\text { Appointment Of President } \\
\text { And Accountability }\end{array}$ & $\begin{array}{c}\text { Power To Grant And } \\
\text { Withdraw Licenses And } \\
\text { Specific Issues Related To } \\
\text { Degree Of Autonomy }\end{array}$ \\
\hline Germany & $\begin{array}{l}\text { Bundesaufsichtsamtfuer das } \\
\text { Kreditwesen (BfC) } \\
\text { Commercial banks. } \\
\text { The Bundesbank has some } \\
\text { supervisory powers from a } \\
\text { market-stability point of view. }\end{array}$ & $\begin{array}{l}\text { The Law sets out a detailed } \\
\text { framework. } \\
\text { The BfC publishes } \\
\text { "interpretations" and } \\
\text { "guidelines" which can be } \\
\text { seen as having a regulatory } \\
\text { power, but they are not } \\
\text { binding. }\end{array}$ & $\begin{array}{l}\mathrm{BfC} \text { is an independent } \\
\text { federal agency under the } \\
\text { auspices of the MOF. BfC } \\
\text { has no own budget. Banks } \\
\text { pay fees to the government } \\
\text { and these fees form } \\
90 \text { percent of the govern- } \\
\text { ment budgetary allocation } \\
\text { for BfC. }\end{array}$ & $\begin{array}{l}\text { BfC reports to the } \mathrm{MOF} \text {, } \\
\text { but must keep close contact } \\
\text { with the Bundesbank. }\end{array}$ & $\begin{array}{l}\text { BfC is the licensing } \\
\text { authority. } \\
\text { The institutional setup } \\
\text { between BfC and the } \\
\text { Deutsche Bundesbank is } \\
\text { currently under discussion. }\end{array}$ \\
\hline H & & & & & \\
\hline
\end{tabular}




\section{Overview of Features of Autonomy of Banking Supervisors in Selected Countries}

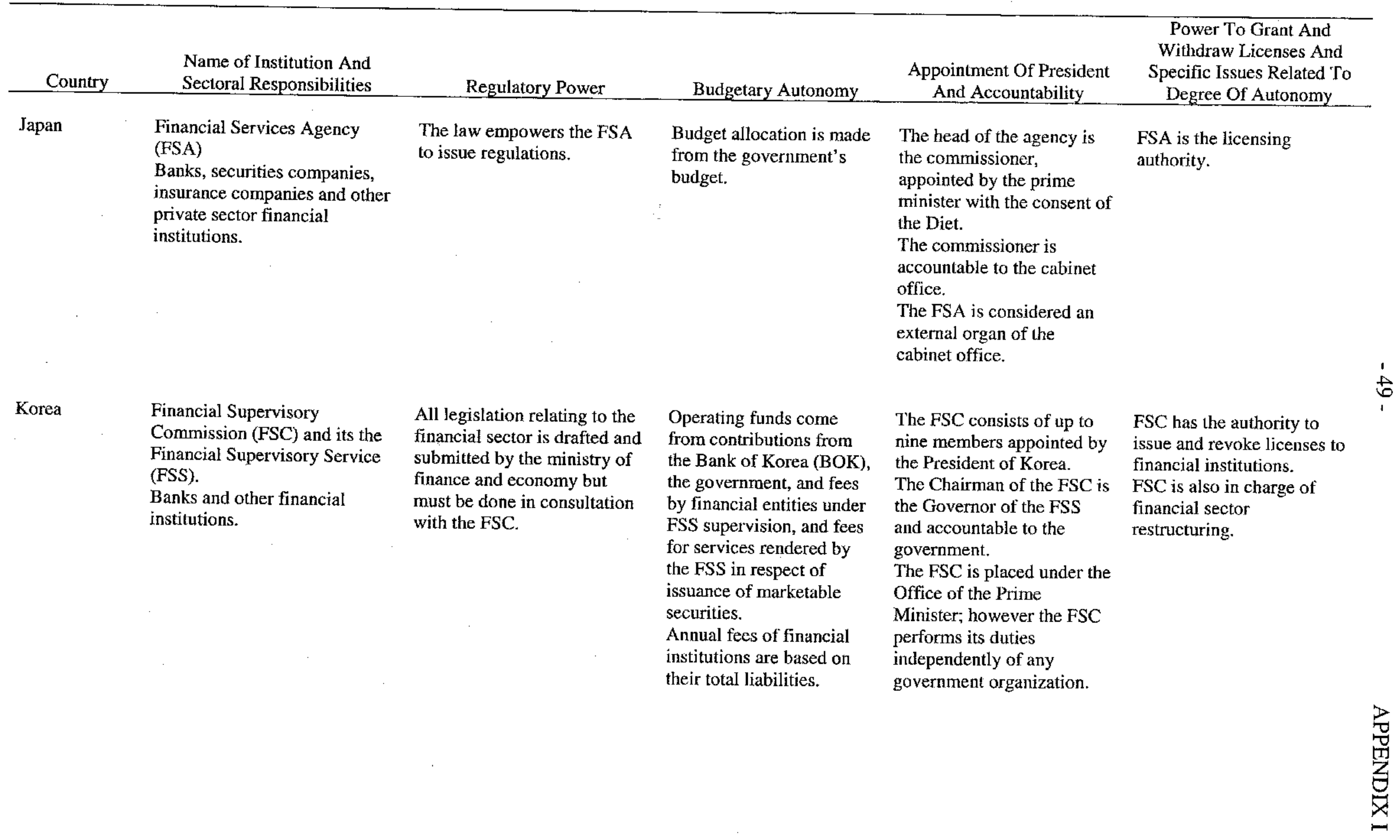


Overview of Features of Autonomy of Banking Supervisors in Selected Countries

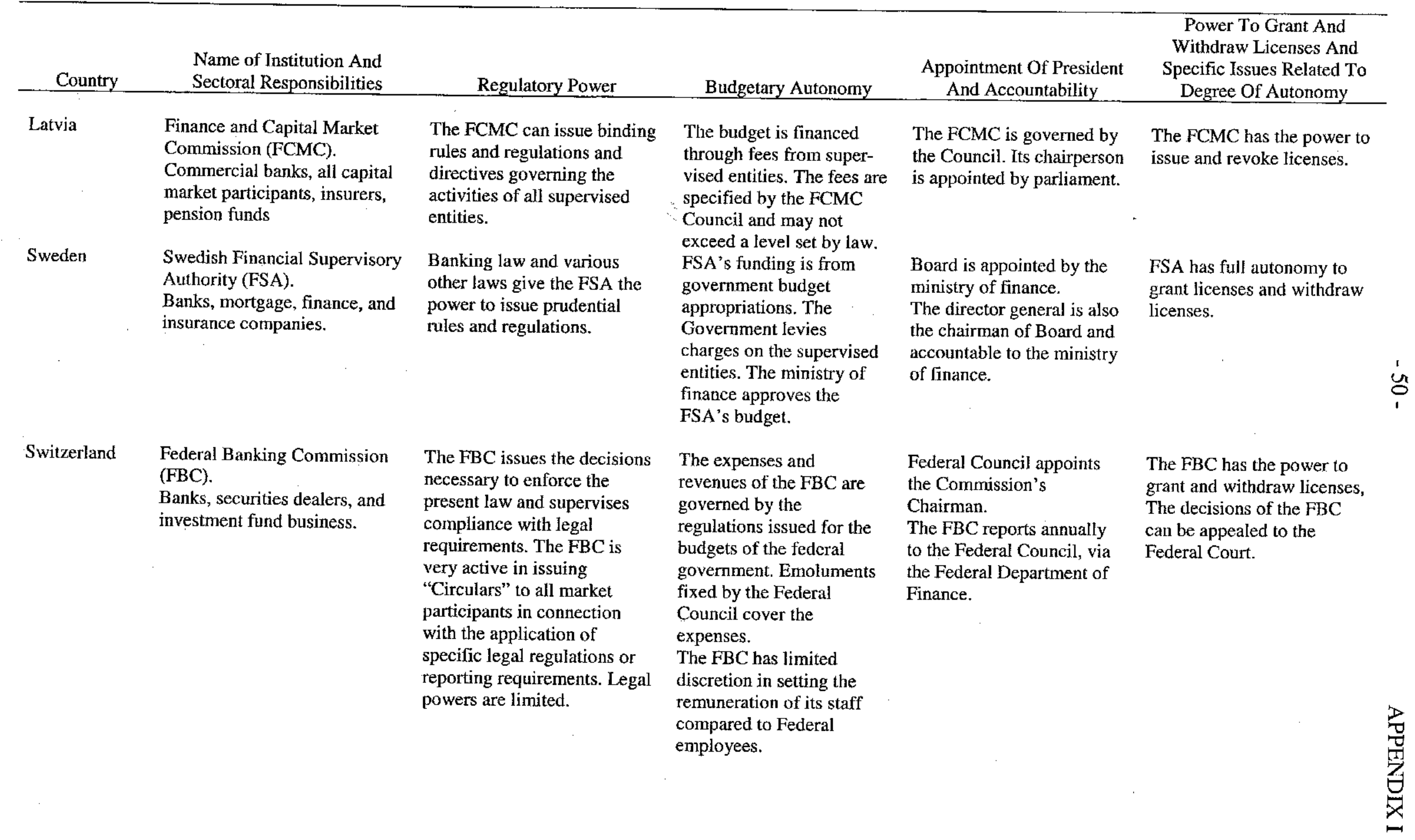




\begin{tabular}{|c|c|c|c|c|c|}
\hline Country & $\begin{array}{l}\text { Name of Institution And } \\
\text { Sectoral Responsibilities }\end{array}$ & Regulatory Power & Budgetary Autonomy & $\begin{array}{l}\text { Appointment Of President } \\
\text { And Accountability }\end{array}$ & $\begin{array}{c}\text { Power To Grant And } \\
\text { Withdraw Licenses And } \\
\text { Specific Issues Related To } \\
\text { Degree Of Autonomy }\end{array}$ \\
\hline $\begin{array}{l}\text { United } \\
\text { Kingdom }\end{array}$ & $\begin{array}{l}\text { Financial Services Authority } \\
\text { (FSA). } \\
\text { Banks and investment } \\
\text { business. }\end{array}$ & $\begin{array}{l}\text { The FSA is empowered to } \\
\text { make regulations within its } \\
\text { field of competence. The FSA } \\
\text { enjoys broad discretion in the } \\
\text { exercise of these powers, } \\
\text { although they must be } \\
\text { exercised consistently with its } \\
\text { statutory objectives. }\end{array}$ & $\begin{array}{l}\text { FSA has its own budget, } \\
\text { which it consults on with } \\
\text { the industry. FSA levies } \\
\text { fees. } \\
\text { FSA is a "private company } \\
\text { limited by guarantee" } \\
\text { FSA has autonomy in } \\
\text { staffing. }\end{array}$ & $\begin{array}{l}\text { Chairman and Board of } \\
\text { FSA are appointed by and } \\
\text { dismissible by the treasury } \\
\text { (appointment is for no fixed } \\
\text { term). Parliament conducts } \\
\text { "confirmation" hearings, } \\
\text { although not on a statutory } \\
\text { basis. } \\
\text { The Chairman is directly } \\
\text { responsible to parliament } \\
\text { for banking supervision. }\end{array}$ & $\begin{array}{l}\text { FSA is empowered to grant } \\
\text { or revoke licenses to conduct } \\
\text { financial services business. } \\
\text { Its decisions may be } \\
\text { appealed to a specialist } \\
\text { tribunal. }\end{array}$ \\
\hline \multirow[t]{2}{*}{ United States } & $\begin{array}{l}\text { Federal Deposit Insurance } \\
\text { Corporation (FDIC) } \\
\text { State banks nonmembers, } \\
\text { industrial banks, savings banks, } \\
\text { foreign bank branches state and } \\
\text { federally licensed. }\end{array}$ & $\begin{array}{l}\text { Federal regulatory agencies } \\
\text { can issue prudential } \\
\text { regulations within the } \\
\text { confines established by the } \\
\text { law. }\end{array}$ & $\begin{array}{l}\text { FDIC is an independent } \\
\text { agency created by } \\
\text { congress. } \\
\text { Funding comes from } \\
\text { premium that it charges on } \\
\text { insurance. } \\
\text { FDIC has full autonomy in } \\
\text { terms of staffing, salaries, } \\
\text { and other budgetary } \\
\text { matters. }\end{array}$ & $\begin{array}{l}\text { Chairman and members of } \\
\text { the Board of Directors, } \\
\text { appointed by president, and } \\
\text { confirmed by the senate. } \\
\text { The heads of the OCC and } \\
\text { OTS serve on FDIC Board. }\end{array}$ & $\begin{array}{l}\text { The FDIC does not grant } \\
\text { charters (licenses) and } \\
\text { cannot remove them, but it } \\
\text { must approve all banks for } \\
\text { deposit insurance and can } \\
\text { remove insurance coverage } \\
\text { without approval of other } \\
\text { agencies, the U.S. Treasury, } \\
\text { or the White House. }\end{array}$ \\
\hline & $\begin{array}{l}\text { Comptroller of the Currency } \\
\text { (OCC). } \\
\text { National banks and foreign } \\
\text { bank branches federally } \\
\text { licensed. }\end{array}$ & Same principles as above. & $\begin{array}{l}\text { Is an "independent" } \\
\text { bureau of the U.S. } \\
\text { Treasury. } \\
\text { Funding comes through } \\
\text { assessment on the banks. } \\
\text { OCC has discretion in } \\
\text { staffing and salaries. }\end{array}$ & $\begin{array}{l}\text { Comptroller of the currency } \\
\text { is appointed by the } \\
\text { president and confirmed by } \\
\text { the senate. }\end{array}$ & $\begin{array}{l}\text { OCC has independence in } \\
\text { granting and revoking } \\
\text { licenses. }\end{array}$ \\
\hline
\end{tabular}


Overview of Features of Autonomy of Banking Supervisors in Selected Countries

\begin{tabular}{|c|c|c|c|c|c|}
\hline Country & $\begin{array}{l}\text { Name of Institution And } \\
\text { Sectoral Responsibilities }\end{array}$ & Regulatory Power & Budgetary Autonomy & $\begin{array}{l}\text { Appointment Of President } \\
\text { And Accountability }\end{array}$ & $\begin{array}{c}\text { Power To Grant And } \\
\text { Withdraw Licenses And } \\
\text { Specific Issues Related To } \\
\text { Degree Of Autonomy }\end{array}$ \\
\hline & $\begin{array}{l}\text { Federal Reserve System (FRS) } \\
\text { All U.S. bank holding } \\
\text { companies and their nonbank } \\
\text { and foreign subsidiaries. }\end{array}$ & Same principles as above. & $\begin{array}{l}\text { Funding is derived from } \\
\text { central banking activities; } \\
\text { staffing levels, salaries, } \\
\text { and other budgetary } \\
\text { matters are set by the } \\
\text { FRS's Board Members. }\end{array}$ & $\begin{array}{l}\text { Chairman and Board } \\
\text { members appointed by the } \\
\text { president and confirmed by } \\
\text { the senate; director of the } \\
\text { Division of Banking } \\
\text { Supervision and Regulation } \\
\text { selected and accountable to } \\
\text { the Board. }\end{array}$ & $\begin{array}{l}\text { FRS approves membership } \\
\text { to the Federal Reserve } \\
\text { System for state-chartered } \\
\text { banks, and the creation of } \\
\text { bank holding companies and } \\
\text { financial holding companies. }\end{array}$ \\
\hline
\end{tabular}

\section{Countries with other types of institutional arrangements}

Finland
FSA issues regulations to the supervised entities concerning the observance of the applicable regulations, and issues guidelines that are necessary for purposes of supervision.

Regulatory autonomy is limited, however.

\section{Operating costs are covered by \\ supervision fees and specific fees paid by supervised entities.}

The President of the Republic appoints the director general of the FSA on recommendation of member of the

Parliamentary Supervisory Council (PSC).

The FSA is accountable to the PSC only with respect to administrative matters.
The MOF has the responsibility for licensing and revocation of a credit institution's license. finance.

Banks, brokerage

firms, stock and derivatives

exchanges, and management companies for mutual funds. 


\section{Overview of Features of Autonomy of Banking Supervisors in Selected Countries}

\begin{tabular}{|c|c|c|c|c|c|}
\hline Country & $\begin{array}{l}\text { Name of Institution And } \\
\text { Sectoral Responsibilities }\end{array}$ & Regulatory Power & Budgetary Autonomy & $\begin{array}{l}\text { Appointment of Presi } \\
\text { And Accountability }\end{array}$ & $\begin{array}{c}\text { Power To Grant And } \\
\text { Withdraw Licenses And } \\
\text { Specific Issues Related To } \\
\text { Degree Of Autonomy }\end{array}$ \\
\hline Thailand & $\begin{array}{l}\text { Ministry of finance } \\
\text { and Bank of } \\
\text { Thailand. Banks, } \\
\text { credit foncier and } \\
\text { finance companies. }\end{array}$ & $\begin{array}{l}\text { The minister of finance is the } \\
\text { regulatory authority. } \\
\text { The Supervision Department and } \\
\text { Financial Institution Policy } \\
\text { Department do the actual on- } \\
\text { and off-site supervision and } \\
\text { formulate the regulatory } \\
\text { framework and policies } \\
\text { concerning financial institutions. }\end{array}$ & Government budget. & $\begin{array}{l}\text { The governor and deputy } \\
\text { governor are appointed by } \\
\text { the crown upon } \\
\text { recommendation of the } \\
\text { cabinet. Accountable to the } \\
\text { minister. }\end{array}$ & $\begin{array}{l}\text { Licensing authority is the } \\
\text { ministry of finance. }\end{array}$ \\
\hline
\end{tabular}

Note on EMU countries: EMU Article 25.1. The ECB may offer advice to and be consulted by the Council, the Commission, and the competent authorities of the member states on the scope and implementation of legislation relating to prudential supervision of credit institutions and the stability of the financial system.

Sources: National central bank laws, laws on supervisory agencies, and laws on financial institutions; Banking Supervision Regulatory Database and Central Bank Legislation Database, IMF; Bank Regulation and Supervision Database, World Bank Group; and Courtis (2001). 